\title{
Physical Cues of Partner Quality
}

\author{
Ian D. Stephen ${ }^{1,2}$, Severi Luoto ${ }^{3,4}$ \\ In: The Oxford Handbook of Evolutionary Psychology and Romantic Relationships
}

\footnotetext{
${ }^{1}$ Department of Psychology, Macquarie University, Sydney, Australia

${ }^{2}$ Perception in Action Research Centre, Macquarie University, Sydney, Australia

${ }^{3}$ English, Drama and Writing Studies, University of Auckland, Auckland, New Zealand

${ }^{4}$ School of Psychology, University of Auckland, Auckland, New Zealand
}

\section{Cite as:}

Stephen, I. D., \& Luoto, S. (in press). Physical cues of partner quality. In J. K. Mogilski \& T. K. Shackelford (Eds.), The Oxford Handbook of Evolutionary Psychology and Romantic Relationships. Oxford, UK: Oxford University Press.

Correspondence: ian.stephen (a) mq.edu.au

Word count: 9775 (body text only), 16554 (including abstract, body text, and references) 


\begin{abstract}
The dominant evolutionary theory of sexual attraction posits that attraction serves as a psychological mechanism for identifying healthy, fertile, and appropriate mates. According to this theory, humans and animals display cues that reflect their mate quality and are perceived as attractive by potential mates. There is evidence for such valid cues in human faces, bodies, and in non-bodily traits, which include adornments and items that signal provisioning ability, creativity, artistic skills, or conspicuous consumption. In this chapter, we discuss the evidence for the existence of these facial, bodily, and non-bodily cues, and for their role in communicating aspects of partner quality, including health, fertility, developmental stability, genetic quality, and potential for parental investment. We further discuss sex differences in the kinds of physical cues that men and women rely on in mate choice. We conclude by noting how central and evolutionarily important physical cues are even in contemporary sexual selection, and how the importance of physical cues of partner quality manifests in evolutionarily novel inventions such as physical self-enhancements, social media, and online dating.
\end{abstract}




\section{Introduction}

"Beauty, [noun]: the power by which a woman charms a lover and terrifies a husband." -Ambrose Bierce

"Since brass, nor stone, nor earth, nor boundless sea, But sad mortality o'ersways their power, How with this rage shall beauty hold a plea, Whose action is no stronger than a flower? $\mathrm{O}$, how shall summer's honey breath hold out Against the wrackful siege of battering days, When rocks impregnable are not so stout, Nor gates of steel so strong, but Time decays?

O fearful meditation! where, alack, Shall time's best jewel from time's chest lie hid?"

-William Shakespeare, Sonnet 65

It has long been recognized that individuals of many species prefer to mate with individuals with certain physical traits (Darwin, 1871). Since this initial observation, debate has focused on whether physical trait preferences are arbitrary (i.e., a result of cultural biases [Wolf, 1990] or biases in the visual system [Fisher, 1930]), or whether they act as cues to some aspect of underlying partner quality, such as a strong immune system, good state of health, or positive personality traits (Thornhill \& Gangestad, 1999). This latter hypothesis has come to dominate evolutionary thinking about mate selection, with attraction being understood as an evolved psychological mechanism for identifying healthy, fertile, high-quality mates (Lee et al., 2008), and attractive cues understood as valid cues to underlying physiological or psychological quality (Coetzee et al., 2009; Stephen et al., 2015). A wide range of physical traits in the human face and body, and indeed beyond the body, have been proposed as valid cues to aspects of partner quality. To be considered a valid cue to partner quality, the cue must both be perceived as 
healthy or attractive, and reflect some aspect of underlying quality (Coetzee et al., 2009; Stephen et al., 2015). In this chapter, we consider the evidence for the quality-cueing properties of facial, bodily, and non-bodily cues (Fig. 1).
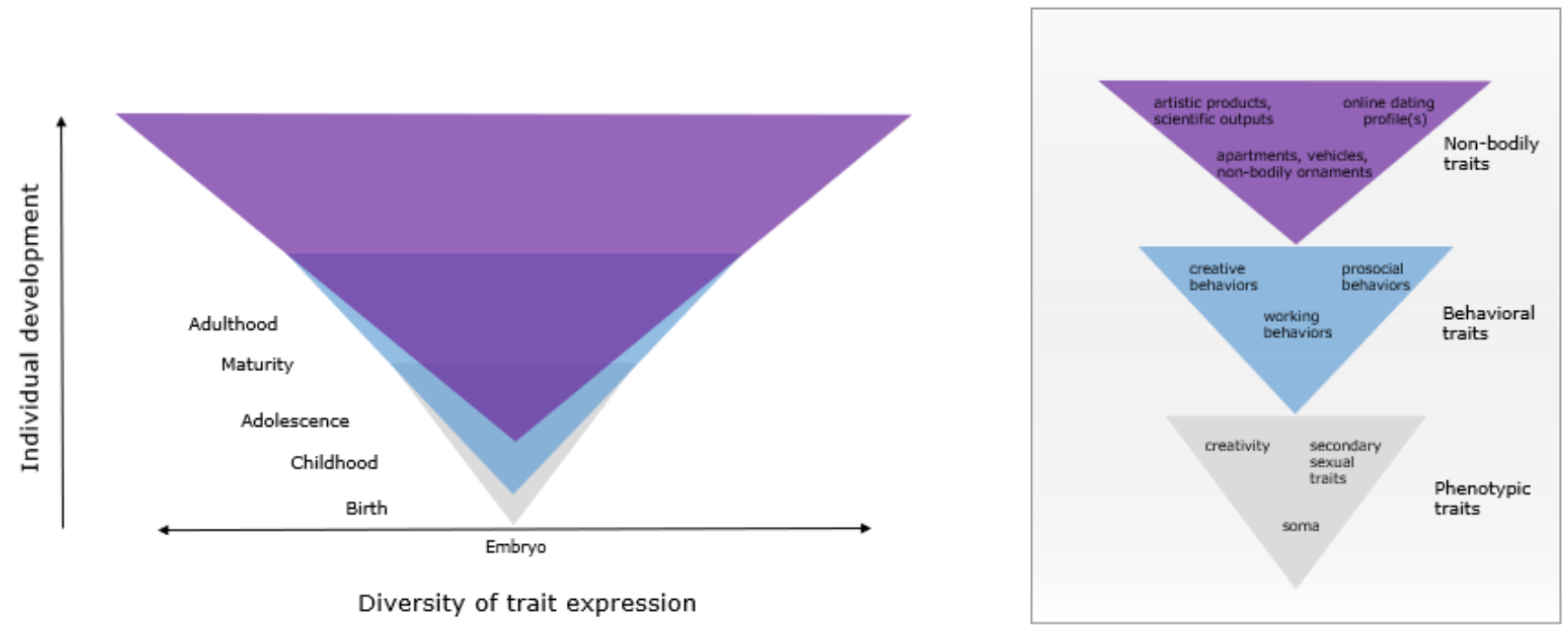

Fig. 1. Three categories of sexual traits projected as a function of individual development. Category-specific examples are presented in the right-hand panel. The lowest triangle (gray) represents phenotypic traits (e.g. physical attractiveness, facial symmetry, and secondary sexual signals). The second triangle (blue) represents behavioural traits (e.g. artistic, prosocial, construction, and working behaviours). The third triangle (purple) represents non-bodily traits (e.g. artistic products, vehicles, online dating profiles, apartments, and pets). The examples in these categories are not exhaustive. The triangles overlap vertically because each successive category starts to develop in ontogeny before the earlier stage ceases to develop. Each successive category occupies more space on the $\mathrm{x}$-axis because the quantity of sexual traits grows with each successive trait category: that is, behavioural traits are hypothetically more diverse than phenotypic traits, and non-bodily traits are hypothetically more diverse than behavioural traits (Luoto, 2019a). Adapted by permission from Springer, Adaptive Human Behavior and Physiology, "An updated theoretical framework for human sexual selection: From ecology, genetics, and life history to extended phenotypes", Luoto, S., (C) 2019. 
The benefits of having evolved mechanisms for identifying high-quality mates may be twofold: a high-quality partner may be better able or willing to provide direct benefits (benefits that accrue to the chooser), such as protection from violence, gifts such as money, food, or access to high-quality territory, or investment into offspring (Luoto, 2019a; Trivers, 1972). A highquality partner may also provide indirect benefits (benefits that accrue to the offspring) such as good genes (Fisher, 1930; Jones \& Ratterman, 2009). Individuals who are able to identify cues to mate quality may therefore secure better access to both direct and indirect fitness benefits, thus enhancing their reproductive success and providing a selection pressure which favours genes that enhance successful identification of a partner's quality.

A range of potential cues to mate quality have been proposed, with different facial, bodily, and non-bodily cues hypothesized to provide information about different aspects of mate quality (Luoto, 2019a; Stephen et al., 2015). From an evolutionary point of view, these can be divided into four categories: cues to health during development, cues to current condition, cues to genetic quality, and cues to psychological traits. We discuss each in turn, and conclude this chapter by focusing on non-bodily traits in human sexual selection.

\section{Cues to developmental health}

Symmetry

A number of facial cues have been proposed as valid cues to an individual's health status during development. For example, low levels of fluctuating asymmetry (i.e., slight, random deviations from true symmetry) are perceived as attractive, with observers rating more symmetrical faces as more attractive than less symmetrical ones (Penton-Voak et al., 2001). Further studies using experimental designs have confirmed the causal nature of this relationship, with participants 
choosing symmetrised versions of faces as more attractive than original versions in forced choice tasks in Western populations (Perrett et al., 1999), in traditional societies such as the Hadza (Little et al., 2007), and even in rhesus macaques (Waitt \& Little, 2006). Further, such preferences for symmetry have been found in a wide range of animal taxa, with individuals preferring to mate with more symmetrical opposite-sex conspecifics (Møller \& Thornhill, 1998). A relationship between the cue of symmetry and perceived attractiveness is therefore well established. However, the relationship between symmetry and physiological or psychological health during development, which is also required to conclude that symmetry is a valid cue to developmental health, is less well established.

Researchers have theorised that increased deviations from true symmetry reflect developmental instability (Gangestad et al., 1994). The hypothesis is that, during gestation, childhood and adolescence, interruptions to development—which may include challenges such as malnutrition, injury, or invasion by pathogens - result in deviations from symmetry, and these deviations accumulate until adulthood is reached (Gangestad et al., 1994). A number of studies have attempted to establish a relationship between health during development and levels of facial asymmetry, with little success. Rhodes et al. (2001) found that the measured symmetry of a sample of 316 17-year-olds was not associated with health scores obtained from physicians' examination of the participants' medical records from childhood and adolescence (Rhodes et al., 2001). A study of 4732 British 15-year-olds from the ALSCAP longitudinal study found that symmetry, as measured from 3D facial scans, was not predictive of a range of measures of childhood health collected during development (Pound et al., 2014). A study on Latvian young men found a positive correlation between family income during ontogeny and immune function, and a negative correlation between immune function and facial asymmetry. The results indicate 
that facial asymmetry may be a reliable cue of the robustness of immune function (Luoto et al., forthcoming), although other studies in African and Polish populations have not found such a relationship when measuring facial (Phalane et al., 2017) or bodily symmetry (Pawłowski et al., 2018) and the robustness of immune function. While symmetry, then, is perceived as healthy and attractive, there is limited evidence that it reflects aspects of health during development.

\section{Sexual dimorphism}

Sexual dimorphism (also referred to as "sex typicality" or "masculinity/femininity") is also proposed to act as a valid cue to health during development (Fink \& Penton-Voak, 2002; Thornhill \& Gangestad, 1999). Sex-typical traits develop under the influence of sex hormones, with testosterone driving the development of taller stature, increased muscularity, increased body and facial hair, and growth of the jaw, nose, and brow ridges in men (Penton-Voak \& Chen, 2004). Conversely, oestrogen is associated with the development of larger breasts, buttocks, and lips, and the inhibition of the growth of body and facial hair, nose, jaw, and brow ridges (Javed

\& Lteif, 2013; Law Smith et al., 2006). The degree of sexual dimorphism is thought to be largely fixed by the end of puberty, so it is hypothesised that sexual dimorphism may act as a valid cue to hormone levels during development (Luoto, Krams, \& Rantala, 2019; Swift-Gallant et al., 2020).

\section{Femininity}

It is well-established that increased femininity of women's faces is perceived as more attractive. When presented with a series of women's faces that had been transformed to appear more feminine (i.e., more typically female) or masculine (i.e., more typically male), participants chose feminised versions of the faces as appearing more attractive (Perrett et al., 1998). This effect has 
been replicated in Western, Asian (Perrett et al., 1998), and African (Coetzee et al., 2014) human populations, though men from countries with higher national health index have greater preference for femininity in women's faces than men from countries with a lower national health index (Marcinkowska et al., 2014). Oestrogen is critical to the functioning of the female reproductive system, with evidence suggesting that women with higher levels of oestrogen are more likely to conceive, both naturally and when undergoing in vitro fertilisation (IVF; Baird et al., 1997, 1999; Lipson \& Ellison, 1996). Further, women with higher levels of circulating oestrogen and progesterone are perceived as healthier, more attractive, and more feminine (Law Smith et al., 2006), suggesting that facial femininity may act as a valid cue to fecundity.

There is further evidence that a feminine body shape (associated with higher oestrogen levels in women) is perceived as attractive. Women with a lower waist-to-hip ratio (WHR) have been shown to be perceived as more attractive than women with a higher WHR; specifically, waist circumference that is approximately $0.7 \mathrm{x}$ hip circumference is rated highest on attractiveness (Cornelissen et al., 2009; Singh, 1993a, 1993b; Tovée \& Cornelissen, 2001). Studies have also shown that low WHR is associated with a more fecund hormonal profile (Jasieńska et al., 2004, but see Grillot et al., 2014, Bovet, 2019). Indeed, a study of 500 women at a fertility clinic suggests that each 0.1 increase in WHR is associated with a $30 \%$ reduction in the probability of conception each cycle (Zaadstra et al., 1993). There is also evidence that a low WHR is associated with improved cognitive abilities in women and their offspring (Lassek \& Gaulin, 2008), possibly because of a more favourable hormonal profile during development, or because gluteofemoral fat deposits are used as developmental resources for the human brain (Lassek \& Gaulin, 2008). This suggests that low WHR may act as a valid cue to women's current and developmental sex hormone profile and nubility (Lassek \& Gaulin, 2019). However, 
Cashdan (2008) argues that women face a trade-off between a more fecund hormonal profile (low androgen, low cortisol, high oestrogen; associated with low WHR) and a more robust hormonal profile (higher androgen, higher cortisol, lower oestrogen; associated with high WHR), demonstrating that few women, particularly older women and women living in more challenging environments, exhibit a WHR as low as 0.7. While this may be the case, it appears that men living in more challenging environments show a preference for even lower WHR than men living in less challenging environments (Swami et al., 2009). The mechanisms controlling the perception of attractive body shape in men's brains may thus prioritise fecundity above other aspects of health.

Women's enlarged breasts are a sexually dimorphic exaggerated secondary sexual trait that is not found in other primate species (except during lactation). They are thought to have evolved as a sexually selected ornament via intersexual choice (Puts, 2010). A number of studies using a variety of stimuli, such as line drawings (Furnham et al., 1998; Singh \& Young, 1995; Swami et al., 2009), 3D avatars (Pazhoohi et al., 2020; Swami \& Tovée, 2013; Valentova et al., 2017) and photographs (Dixson et al., 2011, 2015; Havlíček et al., 2017), have shown that breast size, shape, symmetry, and firmness influence the perceived attractiveness of women's breasts, typically indicating that women with medium and large breasts are perceived as more attractive, healthy, young, and fertile than women with small or very large breasts (Furnham et al., 1998; Havlíček et al., 2017; Pazhoohi et al., 2020; Singh \& Young, 1995; Swami et al., 2009; Valentova et al., 2017). Larger breasts are associated with higher levels of circulating oestradiol (Jasieńska et al., 2004), a correlate of fecundity, suggesting that men who prefer mating with women with larger breasts may have acquired a reproductive advantage over men without such a preference. However, there is also evidence that women with larger breasts are at higher risk of 
developing breast cancer (Scutt et al., 1997). Increased breast cancer risk may provide a balancing selection pressure that prevents the evolution of men's preferences for very large breasts. However, this selection pressure is relatively novel, as breast cancer risk has seen a sharp increase only with the advent of agriculture and the resulting dietary, energetic, and life history changes (Crespi \& Summers, 2005). Another study reported that women's breast size was positively correlated with the number of respiratory infections but not with digestive infections (Kościński et al., 2020). As breast size is positively correlated with body symmetry, and as symmetry is associated with developmental stability, the development of large, sexually attractive breasts is optimised in stable developmental environments (Kościński et al., 2020).

There is also evidence that firmer breasts, and breasts with less ptosis (i.e., sagging) are perceived as more attractive (Havlíček et al., 2017; Pazhoohi et al., 2020), particularly breasts with a 45:55 upper-pole (i.e., distance from the nipple to the top of the breast) to lower pole (i.e., distance from the nipple to the bottom of the breast) ratio (Mallucci \& Branford, 2012, 2014). Since women's breasts become less firm and more ptotic with increasing age and increasing parity (i.e., number of children), it has been argued that breast firmness and ptosis represent valid cues to remaining reproductive value (Pazhoohi et al., 2020). Finally, more symmetrical breasts are perceived as more attractive (Møller et al., 1995; Singh, 1995), and women with more symmetrical breasts are more fecund (Møller et al., 1995) and at lower risk of breast cancer (Scutt et al., 1997), again suggesting that breast symmetry may act as a valid cue to health.

\section{Masculinity}

Evidence that masculinity is a valid cue to men's health is more mixed. The immunocompetence handicap hypothesis (IHH; Folstad \& Karter, 1992) suggests that, because testosterone has a suppressant effect on the immune system (Foo et al., 2017), and masculine 
traits develop under the influence of testosterone (Penton-Voak \& Chen, 2004), only high-quality males are able to bear the immunosuppressive effect of the high testosterone levels required to develop strongly masculinised faces and bodies. Women are therefore expected to show a preference for masculine facial appearance and muscular bodies in men. However, studies asking participants to choose between masculinised and feminised versions of men's faces typically find either no preference for masculinity (Swaddle \& Reierson, 2002; Scott et al, 2010; Stephen et al, 2012) or a preference for feminised faces (Mogilski \& Welling, 2017; Perrett et al., 1998;

Stephen et al, 2018), possibly because high testosterone levels and masculine facial shapes are associated with personality traits that are detrimental within long-term partnerships (e.g., aggression and infidelity; Lee et al., 2017; Mazur \& Booth, 1998; Perrett et al., 1998). This hypothesis suggests that women's mate selection mechanisms may be performing a trade-off between masculine men who may have "good genes" but personality traits that are undesirable in a long-term partner and father, and feminine men who may be less prone to aggressive behaviour and are more suitable as husbands and fathers. Further evidence for this hypothesis comes from studies showing that women's preferences for men's facial masculinity changes depending on the (internal and external) environment. For example, women living in societies with high levels of income inequality, pathogen prevalence, and poor health outcomes show stronger preferences for masculinity in men's faces compared to women in countries with low levels of inequality and good health outcomes (Brooks et al., 2011; DeBruine et al., 2010; Moore et al., 2013). However, the opposite results were found in a more recent study: women had stronger preferences for facial masculinity in countries with higher health indices, lower pathogen prevalence, and greater indices of economic and social development (Marcinkowska et al., 2019), which indicates that 
earlier assumptions about the link between women's facial masculinity preferences in socioecologically harsh conditions may need to be revised.

Similarly, there is evidence that women's preferences for men's facial masculinity fluctuates according to phase of the menstrual cycle, with women preferring more masculine men's faces (and therefore good genes) in the fertile phase, and more feminine men's faces (and therefore more paternal personality traits) in the non-fertile phase (Penton-Voak et al., 1999). However, the reliability of these effects has recently been the subject of debate, with competing meta-analyses finding that menstrual cycle effects on mate choice are well supported (Gildersleeve et al., 2014) and unsupported (Wood et al., 2014). More recent studies have also failed to find significant cycle shifts in women's preferences for men's facial masculinity (Dixson et al., 2018; Jones et al., 2018), masculine voices (Jünger, Motta-Mena, et al., 2018), muscular bodies (Jünger, Kordsmeyer, et al., 2018; but see Gangestad et al., 2019), or beardedness (Dixson et al., 2018). The evidence that male facial masculinity is a valid cue to partner quality is therefore mixed or, at minimum, complex.

\section{Cues to current health}

Some facial and bodily traits have been proposed to represent valid cues to aspects of potential partners' current health status, such as nutritional status, parasite and pathogen load, or cardiovascular health.

\section{Adiposity}

One trait proposed as a valid cue to current health is adiposity (i.e., amount of body fat; Coetzee et al., 2009). Coetzee et al. (2009) found that observers showed above-chance accuracy when asked to judge the BMI of people from photographs of their faces. There was also a relationship 
between the apparent adiposity of the faces and how healthy and attractive they appeared: faces near the average level of apparent facial adiposity were perceived as healthiest and most attractive, with faces near the high and low ends of the apparent adiposity scale perceived as less healthy and attractive. Participants with higher BMIs also self-reported more frequent and severe cold and flu bouts, and higher blood pressure, suggesting that facial adiposity may act as a valid cue to health (Coetzee et al., 2009). This hypothesis is supported by another study which reported that facial and bodily adiposity (negatively) and facial attractiveness (positively) are linked to more robust immune function in men (Rantala et al., 2013a). In women, however, facial attractiveness did not predict robustness of immune function (Rantala et al., 2013b) nor current metabolic health (i.e., glucose metabolism, liver functioning, inflammatory markers), although facial attractiveness was negatively associated with lipid profile components detrimental to health (i.e., total cholesterol, LDL, triglycerides) (Żelaźniewicz et al., 2020).

There have also been efforts to identify aspects of facial shape that may act as valid cues to aspects of cardiovascular health. Coetzee et al. (2010) found that facial width-to-height ratio (in men and women), cheek-to-jaw-width ratio (in men and women), and perimeter-to-area ratio (in men only), as measured from 2D facial photographs of African and Caucasian people, predicted BMI.

More recently, researchers have begun to take a data-driven approach to identifying cues to cardiovascular health (Stephen et al., 2017; Tan et al., 2018; Wolffhechel et al., 2015). This has become possible by the application of statistical techniques for analysing the shape, colour, and texture of facial photographs. Geometric morphometric methods (GMM) allow researchers to first standardise the orientation, size, and location of faces, and then to use principal components analysis (PCA) to identify underlying components that explain the variance in the 
shape of a sample of faces. This allows the data to inform the researchers of which facial metrics may be most important, rather than requiring the researchers to make educated guesses in advance. These components can then be used to predict aspects of underlying health, such as BMI. Wolffhechel et al. (2015) found that the GMM approach is significantly more accurate at predicting underlying BMI than Coetzee et al.'s (2010) three metrics. This approach can be applied to other aspects of underlying health, and Stephen et al. (2017) found that GMM techniques can also successfully predict blood pressure and body adiposity from photographs of African, Asian, and Caucasian faces. The models that are produced to predict these aspects of cardiovascular health can also be "reverse-engineered" to manipulate faces to look either higher or lower in body adiposity, BMI, and blood pressure. When presented with a series of such faces and asked to manipulate them to appear as healthy as possible, participants chose faces corresponding to lower BMI and lower adiposity. These shape components may therefore act as valid facial cues to health (Stephen et al., 2017).

\section{Skin colour and texture}

Facial skin quality, particularly colour and texture, have also been proposed to represent valid cues to aspects of current health. Skin colour is determined by the amounts of coloured pigments in the skin — particularly oxyhaemoglobin (bright red), deoxyhaemoglobin (dark, purplish red), melanin (dark yellowy brown), and carotenoids (bright yellow; Edwards \& Duntley, 1939).

When asked to manipulate the colour of the skin portions of facial photographs to make the faces look as healthy as possible, participants chose to increase the skin lightness (CIELab $\left.\mathrm{L}^{*}\right)$, redness $\left(\mathrm{a}^{*}\right)$, and yellowness $\left(\mathrm{b}^{*}\right)$ (Stephen, Law Smith, et al., 2009). These preferences have been argued to reflect a preference for oxygenated over deoxygenated blood colouration (Stephen, Coetzee, et al., 2009), which is associated with improved cardiovascular health 
(Armstrong \& Welsman, 2001; Charkoudian et al., 1999; Panza et al., 1990); and with carotenoid colouration (Stephen et al., 2011), reflective of levels of antioxidant carotenoid pigments obtained from fruit and vegetables in the diet (Alaluf et al., 2002; Stahl et al., 1998). These findings indicate that skin colouration may act as a valid cue to aspects of underlying health. The role of skin colour in predicting the perceived health and attractiveness of faces appears to be replicable across racial groups (Coetzee et al., 2012; Pezdirc et al., 2017; Stephen et al., 2011, 2012; Tan et al., 2017; Tan \& Stephen, 2019; Whitehead et al., 2012, but see Han et al., 2017). Indeed, there is evidence that the human visual system may be particularly sensitive to small differences in the colouration of facial skin, as compared to colour patches or non-face objects (Re et al., 2011; Tan \& Stephen, 2013), suggesting that specialised health-detection mechanisms may be present in the brain.

\section{Cues to genetic quality}

Identifying mates with high genetic quality (i.e., genes for good health, immune function, attractiveness, and other genes that are advantageous for survival and reproduction) is a valuable ability, allowing increased chances for offspring to inherit these "good genes". Selecting a mate with good genes increases the likelihood of survival and reproductive success of offspring, thereby increasing the probability that one's own genes will be passed on to subsequent generations (Fisher, 1930). While "good genes" can refer to any area of the genome that impacts on health or other traits, research in this area has typically focused on the major histocompatibility complex (MHC; also known as the human leukocyte antigen, HLA, in humans), a part of the genome that determines our ability to distinguish pathogens from our own body's cells. Male height and muscularity may constitute other relevant cues of genetic quality. We discuss the evidence for MHC, height, and muscularity in turn below. 


\section{Major histocompatibility complex}

MHC diversity can act as a cue to mate quality in two ways. First, individuals who are heterozygous at a greater number of alleles in the MHC are thought to be better able to fight off pathogens either because they are able to detect a broader range of pathogens by producing a broader array of antibodies (Brown, 1997, 1999), or by being better able to detect new pathogen forms as they mutate (Van Valen, 1973). These individuals may therefore be healthier (Lie et al., 2009) and thus appear more attractive because healthier individuals may be better able to provide direct benefits such as help with parenting, protection, or resources, and indirect benefits by passing on genes for a strong immune system to offspring. MHC heterozygosity is thought to be detectable via (largely unknown) cues in individuals' odour and in facial appearance (Lie et al., 2009), though recent evidence suggests that facial masculinity is not a valid cue of MHC heterozygosity (Zaidi et al., 2019). Studies examining men's and women's preferences for the bodily odour of MHC heterozygous vs. homozygous individuals tend to involve asking participants to wear a t-shirt for a period of time to collect sweat, measuring participant heterozygosity at a number of loci in the MHC, and then asking a second group of participants to smell the sweaty t-shirts and rate them on traits such as attractiveness or pleasantness. Studies on preferences for MHC heterozygosity are relatively rare, but there is some support for the idea, particularly for women's preferences for men's body odour, possibly because MHCheterozygotes' body odour smells less intense (Thornhill et al., 2003; Wedekind et al., 2006). Studies of preferences for the faces of individuals with greater MHC heterozygosity tend to involve genotyping a group of participants who are then photographed. A second group of participants then rates the attractiveness of the photographs of the first group's faces. While results for these studies are mixed, a recent meta-analysis suggests that the evidence favours a 
small preference for faces of potential partners with greater MHC heterozygosity (Winternitz et al., 2017), possibly because the faces of MHC-heterozygous individuals are more average (closer to the population average shape; Lie et al., 2008).

Second, individuals may be expected to be more attracted to potential partners who are dissimilar to themselves in their MHC. By choosing to mate with genetically dissimilar potential partners, individuals can increase the likelihood of their offspring receiving the indirect benefits of being heterozygous at MHC loci, and thus having stronger immune systems (Havlíček \& Roberts, 2009). Evidence that people find the body odour and faces of MHC-dissimilar partners more attractive is mixed, with studies finding both preferences for more MHC-dissimilar (Sorokowska et al., 2018) and preferences for more MHC-similar (Coetzee et al., 2007; Roberts et al., 2005) potential partners. Recent meta-analyses suggest that the evidence is either currently marginally in favour of preferences for MHC-dissimilar potential partners' odours and faces (Winternitz et al., 2017) or supporting no effect in either direction (Havlíček et al., 2020).

\section{Height}

The role of height in human mate choice is important - but in ways that are sex-specific. It is becoming clear that height is a highly polygenic trait (Rotwein, 2020; Stulp \& Barrett, 2016), meaning that its expression is influenced by a large number of genes, besides a number of environmental factors. Estimates of the heritability of height have consistently indicated that $80 \%$ of the variability seen between people is potentially controlled by genes (McEvoy \& Visscher, 2009). But height appears to be more heritable in men than in women. In men, the heritability estimates of height range around $0.87-0.93$, while in women they are lower, between 0.68 and 0.84 (Silventoinen et al., 2003). The remaining variation is caused by environmental factors such as nutrition and disease exposure (Krams et al., 2019; McEvoy \& Visscher, 2009). 
In contemporary populations, women's height does not appear to strongly affect men's perceptions of women's attractiveness. However, in men, taller stature is sometimes associated with greater reproductive success, and there is some evidence suggesting that this link is driven by female preferences for taller men (Stulp \& Barrett, 2016). For example, a study on speeddating reported that women were choosier than men about potential partners' height, and were most likely to choose men $25 \mathrm{~cm}$ taller than themselves. Men, however, were most likely to choose women only $7 \mathrm{~cm}$ shorter than themselves (Stulp et al., 2013). Taller men were choosier than shorter men yet still had a higher likelihood of ending up with a match than shorter men; this is because taller men were more frequently given a 'Yes' response by women and had to compete with fewer rivals than shorter men (Stulp et al., 2013). Women had a narrower preferred height range than men, and women were less likely than men to choose individuals who fell outside of this preference range. Women therefore had a higher strength of preference for male height than vice versa (Stulp et al., 2013). Taller-than-average men have more attractive mates, are more likely to be married, and are favoured as sperm donors (reviewed in Sugiyama, 2015). Overall, the evidence indicates that female mate choice is a likely contributor to the evolution of human sexual dimorphism in size, favouring taller stature in men (Stulp et al., 2013; Stulp \& Barrett, 2016).

Taller men have been shown to be healthier and have lower mortality rates than shorter men (Stulp \& Barrett, 2016). Men's height is positively associated with status, strength, reach, frequency of aggressive acts, and perceived fighting ability (Stulp, Buunk, Verhulst, \& Pollet, 2015; Sugiyama, 2015). Height is moderately correlated with intelligence in children and in adults (Marioni et al., 2014; Sundet et al., 2005), and estimates suggest that between 35\% and $71 \%$ of this correlation may be explained by genetic factors (Sundet et al., 2005; Marioni et al., 
2014). Better cognitive ability in taller men may explain why taller men have higher wages (Böckerman \& Vainiomäki, 2013) than shorter men (up to about $191 \mathrm{~cm}$, above which the effect decreases; reviewed in Krams et al., 2019; McEvoy \& Visscher, 2009).

The relationship between male height and reproductive success may be curvilinear, decreasing after an optimal height has been reached (Sugiyama, 2015). Even though taller men are favoured by women, taller men have lower reproductive success than average-height men in some populations (Stulp \& Barrett, 2016). Increased reproductive success of average-height men in such populations can be driven by their early age at birth of first offspring, which can, in turn, be associated with an elevated likelihood of pairing with shorter women, who have higher reproductive success themselves (Stulp \& Barrett, 2016). This explanation would support assortative mating for height (Stulp et al., 2017), as well as life history hypotheses whereby height is an important somatic trait that requires bioenergetic investment to develop, meaning that taller men have slower life history strategies than shorter men (Krams et al., 2019; Stulp \& Barrett, 2016), spending longer to develop and reproducing later than shorter men. Higher family socioeconomic status during development predicts both greater height and improved immune function in adult men, suggesting that these traits cluster towards the slow end of the life history spectrum (Krams et al., 2019). A study on a similar population of women as the Latvian male sample of Krams et al. (2019), however, found that women's height was not predicted by their family income during development, even though immune function was (Rubika et al., 2020). It is thus possible that the development and expression of male height are condition-dependent in a similar way to many other sexually selected traits, therefore being more sensitive to resource availability than female height (Krams et al., 2019; Rubika et al., 2020). Overall, height can be useful as a cue of good genes, better immunity, higher intelligence, and more resource-rich 
developmental environments in men (Marioni et al., 2014; Krams et al., 2019), making male height an important cue for women for a number of different reasons.

Overall, the female preference for taller-than-average men may result in a range of direct and indirect genotypic and phenotypic advantages accruing to the women and their offspring, though there may also be disadvantages such as increased risk of birth complications in women who are partnered with much taller men (Stulp \& Barrett, 2016).

While men show a much weaker preference for tall partners, women's height is positively associated with improved educational and economic outcomes (Čvorović, 2020), partner's education and occupation status (Murasko, 2020), better health and offspring survival, and reduced mortality and obstetric problems (Stulp \& Barrett, 2016).

\section{Muscularity}

Male muscularity has also been studied as a potential cue to mate quality in humans. While men are approximately $10 \%$ taller than women on average (Gaulin \& Boster, 1985), they are $33 \%$ heavier, have $61 \%$ more total lean muscle mass, $75 \%$ more arm muscle mass, and $90 \%$ higher upper body strength, on average (Lassek \& Gaulin, 2009). The difference in upper body strength is large enough that the median man has greater upper body strength than $99.9 \%$ of women (Lassek \& Gaulin, 2009). When such large sexual dimorphism of a trait is observed, it typically means that there has been sexual selection driving the exaggeration of the trait (viability selection, which is concerned with survival, tends to act more equally on the two sexes than sexual selection, since a trait useful for survival in one sex is typically also useful for survival in the other). 
There is currently debate in the literature over the role of intersexual choice (women preferring to mate with more muscular men) vs. intrasexual competition (men fighting each other over access to women) in the evolution of male muscularity (Kordsmeyer et al., 2018; Puts, 2010). Puts (2010) argued that men's muscularity and the ancestral human environment were more suited for intrasexual contest competition (fighting) than for intersexual choice, since contest competition could facilitate men's monopolization of women's reproductive output, potentially overriding intersexual choice. Further, observers are able to accurately judge men's upper body strength and fighting ability from photographs of their bodies and even from photographs of faces, suggesting that we may have evolved the ability to detect these traits because of their importance in our evolutionary history (Sell et al., 2009). Men's physical dominance — as rated by other men — predicts men's quantitative mating success (measured via sociosexual behaviour), whereas female-judged sexual attractiveness doesn't (Kordsmeyer et al., 2018). These findings provide tentative evidence for a stronger influence of male-male competition than female mate choice on the evolution of men's physical formidability.

Others argue, however, that women's preferences for mating with more muscular men may have also played a significant role in the evolution of men's muscularity, though evidence about the preferred level of muscularity is mixed. Frederick and Haselton (2007) found, using line drawings and computer-generated avatars as stimuli, that moderate muscularity in men was perceived as most attractive by women. Similarly, using empirically derived transformations of body photographs along fat mass and muscularity dimensions, Brierley et al. (2016) found that levels of fat and muscularity that were in line with health guidelines were perceived as most attractive and healthy in men's bodies. Others have found, using regression models of ratings of 
photographs, that perceived physical strength strongly predicts men's attractiveness: the stronger the men appear, the more attractive they are rated (Lassek \& Gaulin, 2009; Sell et al., 2017).

The aspects of physiological health that muscularity is thought to communicate is also a matter of debate. While some argue that the preference for moderate levels of lean muscularity is indicative of muscularity being a valid cue to good current cardiovascular health (Brierley et al., 2016), others argue that the preference for high levels of muscularity indicates that muscularity acts as a handicapping sexual signal (Folstad \& Karter, 1992). According to this hypothesis, muscularity conveys information about the man's genes which provide him with the ability to maintain a high level of circulating testosterone while maintaining good immune function and the calorific costs of increased muscularity, all the while maintaining other bodily functions (Frederick \& Haselton, 2007; Lassek \& Gaulin, 2009; Sell et al., 2017). So, while it is clear that muscularity does influence the apparent strength and attractiveness of men, the details are less clear, and more research is required to determine its link with underlying health.

\section{Cues to personality}

There have been a number of attempts to identify the aspects of facial appearance that are associated with different personality traits. For example, there is some evidence that individuals who express a preference for certain personality traits in a romantic partner find the faces of opposite-sex people who report that personality trait more attractive (Little et al., 2006). There is also evidence that sociosexuality (openness to casual sex) (Boothroyd et al., 2008, 2011) and intelligence (Zebrowitz et al., 2002) may be visible in the face, though the facial traits that convey the information are unknown. Further studies examining the relationship between self- 
reported personality traits, measured using questionnaires, and perceived personality traits, as rated from facial photographs, have found that observers can accurately perceive extraversion, agreeableness, emotional stability (Penton-Voak et al., 2006), openness, and neuroticism (Kramer \& Ward, 2010). Likewise, personality traits that observers associated with babyfacedness (i.e., weakness and approachability) were also reported by individuals with higher

levels of babyfacedness (Berry \& Brownlow, 1989; Paunonen et al., 1999). Recently, analyses of 3D facial scans have shown that some aspects of facial shape are predictive of personality traits (Hu et al., 2017; Jones et al., 2012). Conversely, while large breasts are perceived by observers as cues of increased willingness to engage in casual sex, larger breasts are not actually associated with women's sociosexuality (Kościński et al., 2020). Overall, however, behavioural traits convey personality-related information more reliably than physical ones (e.g., Miller \& Todd, 1998; Buss \& Penke, 2015).

\section{The role of non-bodily traits in sexual selection}

As seen above, the role of facial and bodily traits in human mate choice has been extensively studied. But partner quality can be communicated also by traits that are not limited to the human body. These non-bodily traits may range from luxurious apartments and cars to other culturally salient products like paintings, novels, musical recordings, and other creative artefacts. Think, for example, how limited the signalling capacity of William Shakespeare, Jimi Hendrix, or Hugh Hefner would have been if they only had their bodily traits with which to signal their mate quality. By using their instruments, creative tools, and surrounding social organisations in new ways, such men have succeeded in amplifying their signalling capacity far beyond what would be possible merely with bodily traits (Luoto, 2019a). Even in contemporary mate choice in 
humans, physical traits that occur outside of the body boundary influence some people's decisions about whom to pursue romantically and with whom to establish a family. It is therefore important to understand how and why such traits influence assessments of partner quality, and an evolutionary approach to the role of non-bodily traits in sexual selection (Luoto, 2019a;

Schaedelin \& Taborsky, 2009) is uniquely positioned to explain this fascinating dimension of mate choice.

The key point to note with most non-bodily traits in human mate choice is that they tend to be difficult to produce, acquire, and fake - and it is also likely that a genetic component explains individual differences in non-bodily ornaments (Luoto, 2019a, 2019b). Hence, showcasing such bioenergetically costly non-bodily traits can signal a number of important qualities about potential mates. In the following sections, we review the existing evidence for the role of non-bodily traits in human sexual selection and discuss sex differences in how such traits are evaluated.

\section{Clothing as an example of non-bodily traits}

"Clothes make the man. Naked people have little or no influence in society." —Mark Twain

"She wore far too much rouge last night and not quite enough clothes. That is always a sign of despair in a woman." - Oscar Wilde, "An Ideal Husband"

As central as physical attractiveness is for evaluating partner quality, it is uncommon in most modern societies, as Mark Twain notes (Vizental, 2010), to flaunt physical attractiveness unveiled by clothing. While clothing has the obvious physiological function of enabling humans 
to occupy ecological niches characterised by cold temperature, clothing has also been exapted for signalling purposes - to convey information about aspects of the bearer's potential as a romantic or social partner (Luoto, 2019a). Clothing can be used strategically to signal important characteristics about one's partner quality and mating motives.

From flamboyant to plain, luxurious to inexpensive, à la mode to dowdy, formal to informal, revealing to concealing, and high-end brands to everyday apparel, clothing can be manipulated on a number of dimensions to send myriad signals to would-be mates. When close to ovulation, for instance, some women tend to prefer clothing that is more revealing and more appealing to men (Durante, Li, \& Haselton, 2008; Eisenbruch, Simmons, \& Roney, 2015). Unsurprisingly, more revealing clothing increases women's attractiveness as a short-term partner (Hendrie, Mannion, \& Godfrey, 2009; Hill, Nocks, \& Gardner, 1987). One possible function of clothing in human mate choice, therefore, is that it is a malleable non-bodily ornament that signals its displayer's mating motives or even mate quality (Elliot, Greitemeyer, \& Pazda, 2013). Women may strategically use clothing in this way; for example, women consciously use clothing to signal their sexual desire and to attract sexual attention from men, wearing more revealing clothing when clubbing, and men perceive sexual intent in women who do so (Hendrie, Chapman, \& Gill, 2020; Lennon et al., 2017). Women are more likely to wear high heels if they anticipate interacting with an attractive male, and are less likely to do so if they anticipate interacting with an unattractive male (Prokop \& Švancárová, 2020). Women’s dyadic sexual desire (i.e., an interest in, or a wish to engage in, sexual activity with another person, and desire for sharing and intimacy with that person) predicts their inclination to buy high-heeled rather than low-heeled shoes (Watkins \& Leitch, 2020). Using high-heeled footwear modifies women's lumbar curvature and gait to be more appealing to men (Lewis et al., 2017; Morris, White, 
Morrison, \& Fisher, 2013). Clothing, above and beyond its own signalling value, can thus be used to augment evolved physiological features in such a way as to appear more attractive to the opposite sex.

On the other hand, clothing can also be used to suppress sexuality, as is the case in the cultural practice of Islamic veiling, which decreases women's rated attractiveness (Pazhoohi \& Kingstone, 2020). Both men and women can advocate veiling as a facultative strategy that suppresses female sexuality and serves the Darwinian fitness interests of those who support the practice (Blake, Fourati, \& Brooks, 2018). A cross-cultural study on veiling reported that in all of the 25 countries included in the analysis, men supported veiling more than women. Veiling may thus serve men's fitness interests more than those of women (Pazhoohi \& Kingstone, 2020), for example by reducing women's attractiveness to men who are not their husband.

Another potential function of clothing is that it signals status, which can be highly important in mate choice contexts. Nevertheless, current evidence on the relationship between clothing-related status and attractiveness is still mixed. Perhaps surprisingly, Gouda-Vossos et al. (2019) found that business attire (as opposed to casual attire) had no effect on how attractive females rated males. Business attire only influenced women's ratings of men's economic status, but not men's attractiveness (Gouda-Vossos et al., 2019). It should be noted that this null finding may have partially been influenced by the fact that some of the business attire stimuli used by Gouda-Vossos et al. (2019, Fig. 3) included a man in a rather ill-fitting business suit, which may have negatively influenced the men's rated attractiveness. Business attire slightly increased ratings of women's attractiveness when compared with women in casual attire in Study 1, whereas Study 2 provided the opposite results: men rated women in business suits as lower on attractiveness than women in casual attire (Gouda-Vossos et al., 2019). These mixed results 
indicate that business as opposed to casual attire may not have a major influence on women's attractiveness. Unsurprisingly, however, business attire slightly increased ratings of women's economic status (Gouda-Vossos et al., 2019). These studies manipulated attire mainly on one or two dimensions (formal vs. informal, and high status vs. normal status). Manipulating attire on more dimensions, such as flamboyant/plain, or revealing/concealing, or trendy/dowdy, could have a stronger influence on perceived attractiveness and partner quality. Other research has shown that women who emphasise their sexiness via clothing in the workplace may be judged to be less competent and less intelligent; outside the workplace, such women may be perceived more negatively by other women, to the extent that women are less likely to befriend or introduce their boyfriends to them (Lennon et al., 2017). Although there is some research on the role of clothing in human sexual selection, this is an area that is under-researched in comparison with many other areas of human mate choice (Luoto, 2019a).

Other non-bodily traits, and sex differences in the importance of non-bodily vs. bodily traits

It is a basic fact of human biology that reproduction is costlier for females than it is for males. This fundamental biological asymmetry can cause various downstream effects on human psychology and behaviour (Archer, 2019; Buss \& Schmitt, 2019). One such widely reported effect is the sex difference in how selective one is about with whom and when to have sex: women, on average, tend to be choosier about their sexual partners, while men, on average, are less restricted with their sexual behaviour (Hughes, Aung, Harrison, Lafayette, \& Gallup, 2020; Luoto, Krams, \& Rantala, 2019). Men, therefore, face ruthless though often tacit competition with one another to be desirable as partners and to acquire sexual access to women-though 
women also have to compete with one another to secure the best males (Baumeister, Reynolds, Winegard, \& Vohs, 2017; Rantala, Luoto, Krama, \& Krams, 2019).

Much research in evolutionary psychology has focused on these reproductive dynamics, and an oft-cited finding is the sex difference in the importance of a partner's status and resources (Archer, 2019; Buss \& Schmitt, 2019; Luoto, 2019a; Scelza \& Prall, 2018). Resource acquisition and provisioning have enhanced male reproductive success throughout human evolution, and sexual selection may have favoured status-seeking behaviours in men (reviewed in GoudaVossos et al., 2019; Luoto, 2019a; Scelza \& Prall, 2018). Men’s status is associated with reproductive success across many small-scale and industrialised societies (reviewed in GoudaVossos et al., 2019; see also Scelza \& Prall, 2018). Resources and status, therefore, offer ways in which men are able to bridge the biological asymmetry between the sexes in minimal parental investment (Trivers, 1972): raising human infants is costly, and men's paternal investment has a clear evolutionary role in increasing the likelihood of raising viable offspring by provisioning resources and by providing a more stable and secure developmental environment for offspring (Kuzawa, 2007; Luoto, 2019a). But which cues do women use in mate choice to acquire information about the potential resource-provisioning ability of a male? And are women's status and resources similarly salient to men?

Although the original function of housing was to provide shelter from the harsh elements of nature and a stable workspace for routine labour such as tool and clothing manufacture, human housing has also taken on a signalling component: the kind of house one occupies may act as a cue of one's status and resource-provisioning capacity (Dunn \& Hill, 2014; Luoto, 2019a). Men presented in a luxury apartment are rated as more attractive by women than men presented in a standard apartment (Dunn \& Hill, 2014). The evolutionarily exapted signalling 
function of housing may not be limited to contemporary societies, nor to humans (Luoto, 2019a; Schaedelin \& Taborsky, 2009). In Jane Austen's classic novel Pride and Prejudice, the heroine's resistance to a prominent male's otherwise unsuccessful courtship efforts undergoes a gradual transformation when she is exposed to the grandeur and style of his territory. While visiting Mr. Darcy's estate, Elizabeth suddenly gets the revelation "that to be mistress of [that territory] might be something!" (Austen, 2007/1813, p. 207). Mr. Darcy's physical and behavioural cues were insufficiently appealing to the heroine, and Mr. Darcy's courtship efforts were, perhaps paradoxically, boosted only when Elizabeth visited his estate in his absence. Though based 'merely' on classic fiction, many of us may be able to conjure up similar examples of mate choice from anecdotal evidence or lived experience. The signalling function of housing is just one example of the evolutionarily important effects that non-bodily traits may have in mate choice (Luoto, 2019a).

Another such example is cars. Besides the obvious function of transportation, cars have acquired important signalling characteristics in the course of human cultural evolution, which has seen cars arise as one of the most prototypical examples of conspicuous consumption and wealth signalling. Men who were seated in a luxurious Silver Bentley Continental GT were rated as significantly more attractive by women than when seated in a Red Ford Fiesta ST (Dunn \& Searle, 2010). This finding about the effects of a luxury vs. a standard car in mate choice has been replicated using other car models in other studies (Shuler \& McCord, 2010; Sundie et al., 2011).

But are men swayed by these non-bodily traits to the same extent as women are? That does not appear to be the case. Women presented in a luxury apartment are rated equally attractive by men as when presented in a standard apartment (Dunn \& Hill, 2014). Likewise, 
women presented in a luxury vs. standard car are not rated as more attractive by men (Dunn \& Searle, 2010). Men are more likely than women to use their car as a cue of their wealth and their phenotypic quality (Belk, 2004), while some men believe that owning the right kind of car is similar to possessing a powerful sexual charm that can render them irresistible to women (Saad \& Vongas, 2009). Why should there be such a sex difference in the importance of non-bodily vs. bodily traits in sexual selection?

The "traditional dating arrangement" where men are expected to court women with gifts and dinners is by no means strictly a human occurrence: it is a broader evolutionary trend that has evolved to counter the sexual asymmetry in parental investment (Lewis \& South, 2012). For instance, the transfer of important material gifts from males to females is common in many arthropod species. In some species, females do not hunt at all, relying instead on food gifts from males (Gwynne, 2008). In wild chimpanzees, food sharing is associated with increased copulation in males who share meat with females over an extended period of time. Male chimpanzees are also more likely to share meat with oestrous than anoestrous females, suggesting that chimpanzees exchange meat for reproductive opportunities (Gomes \& Boesch, 2009). Anthropological evidence in humans has shown that Siriono men in Bolivia obtain extramarital sex with meat gifts (Holmberg, 1969), Mehinaku women in the Amazon use their sexuality to obtain food from men (Gregor, 1985, pp. 36-37), and the Kulina in South America have a ritual practice in which women have sexual intercourse with successful hunters (Pollock, 2002 , p. 53). Some contemporary women engage in foodie calls, that is, going on a date in order to get a free meal. A study on foodie calls found that $33 \%$ of women had engaged in a foodie call, and some engaged in them frequently or very frequently (Collisson, Howell, \& Harig, 2020). We are not aware of any studies on foodie calls in men, and suspect that few men would 
go on dates in hopes of a free meal. In a large contemporary German sample of heterosexual individuals, most men $(75.3 \%)$ could imagine marrying someone who does not have regular employment, but relatively few women $(28.0 \%)$ had marriage interest in such a mate. However, more women (47.7\%) than men (35.2\%) could imagine marrying someone who is not goodlooking (Schwarz \& Hassebrauck, 2012). These findings exemplify the sex difference placed on bodily vs. non-bodily traits, possibly highlighting the greater somatic investment that women make in producing offspring in humans. In the aggregate, men tend to place a higher premium than women on bodily rather than non-bodily traits, whereas women may value men's ability to bridge the sexual asymmetry in parental investment by providing resources (Janicke, Häderer, Lajeunesse, \& Anthes, 2016; Kuzawa, 2007; Luoto, 2019a). Food provisioning is a simple example of resource sharing that can indicate the evolutionarily valuable ability to provide for offspring.

Creativity is another important trait in mate choice, at least once a baseline level of other traits has been satisfied (Li, Bailey, Kenrick, \& Linsenmeier, 2002). In a cross-cultural mate preference study, creativity was ranked the 6th most desirable trait by women and 7th by men (Buss et al., 1990; cf. Zietsch, Verweij, \& Burri, 2012). Creativity takes several different forms, and these forms are not necessarily rated equally desirable by the opposite sex (Kaufman et al., 2014). Sculptures, paintings, musical recordings, and literature can comprise physical cues of their producer's phenotypic and/or genetic quality, and as such, they may influence the sexual attractiveness of the artist (Clegg, Nettle, \& Miell, 2011; Madison, Holmquist, \& Vestin, 2018; Miller, 2001; Winegard, Winegard, \& Geary, 2018). Although there are few studies of how works of art as non-bodily ornaments influence artists' mate value, one study found that written records of men's compliments to women increased a man's attractiveness when the compliments 
were creative rather than trite (Gao, Gao, et al., 2017). A correlational study found that men's success with visual art was a significant predictor of their number of self-reported mating partners - while in female artists such a pattern was not found (Clegg et al., 2011) (see also Varella, Valentova, \& Fernández, 2017 for a broader discussion). Corresponding findings have been reported with literary art and other creative products. Men comprise an overwhelming majority of producers of creative products for public consumption (Kanazawa, 2000; Lange \& Euler, 2014; Miller, 1999). Men are also more motivated to write books than women (Lange, 2011), whereas women are more avid readers of fiction than men and also tend to consume more high-brow culture than men (reviewed in Christin, 2012). These findings support the hypothesis of male supply and female evaluation of creative products (i.e. the 'art as sexual display' hypothesis) that arises from the theory of sexual selection (Crocchiola, 2014; Gao, Yang, et al., 2017; Lange \& Euler, 2014) (for a broader discussion, readers may refer to Varella et al., 2017; Winegard et al., 2018). We note that more research is needed in this area to provide more robust evidence of sex differences in how art is evaluated within a mate choice context.

\section{Evolutionary mismatches in mating}

It is intriguing that such sex differences as reported above exist even in contemporary societies that have undergone millennia of cultural evolution since our ancestral hunter-gatherer past. Wouldn't it be preferable for men to partner up with a wealthier female, all other things being equal, since material wealth will likely increase the likelihood of raising viable offspring in contemporary humans? The findings reviewed above indicate that this may not necessarily be an important consideration for most contemporary males, suggesting that men have not overridden their evolved mate preferences (Buss \& Schmitt, 2019) even if rationally it might in some 
contexts be beneficial for them to do so. What is more, that many women still emphasise the importance of resource-provisioning ability in males (Buss \& Schmitt, 2019; Hughes \& Aung, 2017), either consciously or subconsciously, suggests that sex differences in partner preferences, which are reminiscent of traditional Darwinian gender roles (Archer, 2019; Janicke et al., 2016), still persist despite environmental and cultural novelties, such as some branches of modern feminism and gender equity movement. This highlights the oft-repeated insight from evolutionary psychology: when there has been a rapid change in environmental conditions, individuals may still be adapted to the past and therefore maladapted to the present, engaging in goal-directed behaviours that end up decreasing their fitness (Crespi, 2020; Goetz, Pillsworth, Buss, \& Conroy-Beam, 2019; Li, van Vugt, \& Colarelli, 2018). This outcome may be highly prevalent in contemporary humans, since rapid change in our environments can create cascades of 'mismatches' between evolved psychological mechanisms and the current environment, decoupling behaviour from its formerly adaptive contexts and outcomes (Crespi, 2020; Rantala et al., 2019; Rantala, Luoto, Krams, \& Karlsson, 2018).

Many such mismatches also occur in mating. From an evolutionary point of view, it is important to recognise that our mate choice mechanisms were calibrated in environments where potential mates were evaluated in person by using the full array of cues available to us from in vivo observations of a person's characteristics (Goetz et al., 2019). However, the proliferation of online dating technologies and social networking platforms has generated a new kind of mismatch with interpersonal evaluation and courtship. Physical cues conveyed by a person's online dating profile or in social media may imperfectly (or deceptively) represent the actual underlying mate quality of that person (Goetz et al., 2019; Luoto, 2019a). The ubiquity of contemporary interactions in social media, both with regard to finding and keeping a mate, may 
mismatch our evolved psychological mechanisms—-geared as they are towards in vivo interactions and observing physical cues of potential mates in person. Thus, in contemporary technologically advanced environments, evolved psychological mechanisms which guide human mate choice may be suboptimally adapted to such scenarios in which a handheld mobile device smaller than a stone-age handaxe contains the potentially deceptive virtual representation of physical cues of thousands more potential mates than any ancestral human being would encounter in their lifetimes (Goetz et al., 2019; Luoto, 2019a). This mismatch highlights the importance of an evolutionary understanding of how mate quality is signalled via physical cues, as well as the modern proliferation and potential deceptive modification of such cues in social media. Understanding the evolutionary underpinnings of sexual signalling via physical cues may help people navigate the contemporary complexity of sexual selection and avoid making suboptimal or poorly informed mate choice decisions.

\section{Conclusions}

The human face and body convey a large amount of information, from salient traits such as age, sex, and ancestry, to less obvious information such as nutritional status, hormonal status, and personality. The human body also conveys information about sex via sexually dimorphic and gendered traits, body composition, hormonal status, age, and other traits. In this chapter, we have shown how these physical cues of partner quality can convey information which is essential to successful reproduction, such as a partner's genetic quality, health during development, and current condition. But partner quality can also be inferred from non-bodily objects, including clothes, jewellery, cars, and houses. Given the evolutionary importance of physical cues on sexual selection, it is unsurprising that physical cues of partner quality remain central to the human experience, from Shakespeare's sonnets to visual art, and from the multi-billion-dollar 
industries of fashion, cosmetics, and physical self-enhancement to the "sexy selfies" that have proliferated in recent cultural evolution via Internet, social media, and online dating. Mary Wollstonecraft made the following remark in 1792, which still resonates in contemporary sexual selection: "Taught from infancy that beauty is woman's sceptre, the mind shapes itself to the body, and roaming round its gilt cage, only seeks to adorn its prison.” As evolved mate preferences continue to fixate on evolutionarily and reproductively relevant traits, various bodily and non-bodily physical cues of partner quality will remain highly relevant to human sexual selection, shaping the choices of whom we pursue romantically and with whom we choose to enter committed long-term relationships. 
References

Alaluf, S., Heinrich, U., Stahl, W., Tronnier, H., \& Wiseman, S. (2002). Human nutrition and metabolism: Dietary carotenoids contribute to normal human skin color and UV photosensitivity. Journal of Nutrition, 132, 399-403.

Archer, J. (2019). The reality and evolutionary significance of human psychological sex differences. Biological Reviews, 94(4), 1381-1415. https://doi.org/10.1111/brv.12507

Armstrong, N., \& Welsman, J. (2001). Peak oxygen uptake in relation to growth and maturation in 11- to 17-year-old humans. European Journal of Applied Physiology, 85(6), 546-551. https://doi.org/10.1007/s004210100485

Austen, J. (1813). Pride and Prejudice. Chandni Chowk, Delhi: Global Media.

Baird, D. D., Weinberg, C. R., Zhou, H., Kamel, F., McConnaughey, D. R., Kesner, J. S., \& Wilcox, A. J. (1999). Preimplantation urinary hormone profiles the probability of conception in healthy women. Fertility and Sterility, 71(1), 40-49. https://doi.org/10.1016/S0015-0282(98)00419-1

Baird, D. D., Wilcox, A. J., Weinberg, C. R., Kamel, F., McConnaughey, D. R., Musey, P. I., \& Collins, D. C. (1997). Preimplantation hormonal differences between the conception and non-conception menstrual cycles of 32 normal women. Human Reproduction, 12(12), 2607-2613. http://www.ncbi.nlm.nih.gov/pubmed/9455822

Baumeister, R. F., Reynolds, T., Winegard, B., \& Vohs, K. D. (2017). Competing for love: Applying sexual economics theory to mating contests. Journal of Economic Psychology, 63, 230-241. https://doi.org/10.1016/j.joep.2017.07.009

Belk, R. W. (2004). Men and their machines. Advances in Consumer Research, 31, 273-278.

Berry, D. S., \& Brownlow, S. (1989). Were the Physiognomists Right? Personality and Social Psychology Bulletin, 15(2), 266-279. https://doi.org/10.1177/0146167289152013

Blake, K. R., Fourati, M., \& Brooks, R. C. (2018). Who suppresses female sexuality? An examination of support for Islamic veiling in a secular Muslim democracy as a function of sex and offspring sex. Evolution and Human Behavior, 39(6), 632-638.

Böckerman, P., \& Vainiomäki, J. (2013). Stature and life-time labor market outcomes: Accounting for unobserved differences. Labour Economics, 24, 86-96.

Boothroyd, L. G., Cross, C. P., Gray, A. W., Coombes, C., \& Gregson-Curtis, K. (2011). Perceiving the facial correlates of sociosexuality: Further evidence. Personality and Individual Differences, 50(3), 422-425. https://doi.org/10.1016/j.paid.2010.10.017

Boothroyd, L. G., Jones, B. C., Burt, D. M., DeBruine, L. M., \& Perrett, D. I. (2008). Facial correlates of sociosexuality. Evolution and Human Behavior, 29(3), 211-218. https://doi.org/10.1016/j.evolhumbehav.2007.12.009" https://doi.org/10.1016/j.evolhumbehav.2007.12.009

Bovet, J. (2019) Evolutionary theories and men's preferences for women's waist-to-hip ratio: 
Which hypotheses remain? A systematic review. Frontiers in Psychology, 10:1221. doi: 10.3389/fpsyg.2019.01221

Brierley, M.-E., Brooks, K. R., Mond, J., Stevenson, R. J., \& Stephen, I. D. (2016). The body and the beautiful: Health, attractiveness and body composition in men's and women's bodies. PLoS ONE, 11(6). https://doi.org/10.1371/journal.pone.0156722

Brooks, R., Scott, I. M., Maklakov, A. A., Kasumovic, M. M., Clark, A. P., \& Penton-Voak, I. S. (2011). National income inequality predicts women's preferences for masculinized faces better than health does. Proceedings. Biological Sciences / The Royal Society, 278(1707), 810-814. https://doi.org/10.1098/rspb.2010.0964

Brown, J. L. (1997). A theory of mate choice based on heterozygosity. Behavioral Ecology, 8(1), 60-65. https://doi.org/10.1093/beheco/8.1.60

Brown, J. L. (1999). The new heterozygosity theory of mate choice and the MHC. Genetica, 104(3), 215-221. http://www.ncbi.nlm.nih.gov/pubmed/10386385

Buss, D. M., Abbott, M., Angleitner, A., Asherian, A., Biaggio, A., Blanco-Villasenor, A., ... Deraad, B. (1990). International preferences in selecting mates: A study of 37 cultures. Journal of Cross-Cultural Psychology, 21(1), 5-47.

Buss, D. M., \& Penke, L. (2015). Evolutionary personality psychology. In M. Mikulincer, P. R. Shaver, M. L. Cooper, \& R. J. Larsen (Eds.), APA handbooks in psychology®. APA handbook of personality and social psychology, Vol. 4. Personality processes and individual differences (pp. 3-29). American Psychological Association. https://doi.org/10.1037/14343-001

Buss, D. M., \& Schmitt, D. P. (2019). Mate preferences and their behavioral manifestations. Annual Review of Psychology, 70, 77-110. https://doi.org/10.1146/annurev-psych010418-103408

Cashdan, E. (2008). Waist-to-hip ratio across cultures: Trade-offs between androgen- and estrogen-dependent traits. Current Anthropology, 49(6), 1099-1107. https://doi.org/10.1086/593036

Charkoudian, N., Stephens, D. P., Pirkle, K. C., Kosiba, W. A., \& Johnson, J. M. (1999). Influence of female reproductive hormones on local thermal control of skin blood flow. Journal of Applied Physiologyy, 87(5), 1719-1723. https://doi.org/https://doi.org/10.1152/jappl.1999.87.5.1719

Christin, A. (2012). Gender and highbrow cultural participation in the United States. Poetics, 40(5), 423-443. https://doi.org/10.1016/j.poetic.2012.07.003

Clegg, H., Nettle, D., \& Miell, D. (2011). Status and mating success amongst visual artists. Frontiers in Psychology, 2, 310. https://doi.org/10.3389/fpsyg.2011.00310

Coetzee, V., Barrett, L., Greeff, J. M., Henzi, S. P., Perrett, D. I., \& Wadee, A. A. (2007). Common HLA alleles associated with health, but not with facial attractiveness. PLoS ONE, 2(7), 1-8. https://doi.org/10.1371/journal.pone.0000640

Coetzee, V., Chen, J., Perrett, D. I., \& Stephen, I. D. (2010). Deciphering faces: Quantifiable 
visual cues to weight. Perception, 39(1), 51-61. https://doi.org/10.1068/p6560

Coetzee, V., Faerber, S. J., Greeff, J. M., Lefevre, C. E., Re, D. E., \& Perrett, D. I. (2012). African perceptions of female attractiveness. PloS One, 7(10), e48116.

https://doi.org/10.1371/journal.pone.0048116

Coetzee, V., Greeff, J. M. J. M., Stephen, I. D., \& Perrett, D. I. (2014). Cross-cultural agreement in facial attractiveness preferences: The role of ethnicity and gender. PLOS ONE, 9(7). https://doi.org/10.1371/journal.pone.0099629

Coetzee, V., Perrett, D. I., \& Stephen, I. D. (2009). Facial adiposity: A cue to health? Perception, 38(11), 1700-1711. https://doi.org/10.1068/p6423

Collisson, B., Howell, J. L., \& Harig, T. (2020). Foodie calls: When women date men for a free meal (rather than a relationship). Social Psychological and Personality Science, 11(3), 425-432. https://doi.org/10.1177/1948550619856308

Cornelissen, P. L., Toveé, M. J., \& Bateson, M. (2009). Patterns of subcutaneous fat deposition and the relationship between body mass index and waist-to-hip ratio: Implications for models of physical attractiveness. Journal of Theoretical Biology, 256(3), 343-350. https://doi.org/10.1016/j.jtbi.2008.09.041

Crespi, B. (2020). Evolutionary and genetic insights for clinical psychology. Clinical Psychology Review. https://doi.org/10.1016/j.cpr.2020.101857

Crespi, B., \& Summers, K. (2005). Evolutionary biology of cancer. Trends in Ecology \& Evolution, 20(10), 545-552.

Crocchiola, D. (2014). Art as an indicator of male fitness: Does prenatal testosterone influence artistic ability? Evolutionary Psychology, 12(3), 521-533. https://doi.org/10.1177/147470491401200303

Čvorović, J. (2020). Stature and education among Roma women: taller stature is associated with better educational and economic outcomes. Journal of Biosocial Science, 52(2), 260-271.

Darwin, C. (1871). The Descent of Man and Selection in Relation to Sex.

DeBruine, L. M., Jones, B. C., Crawford, J. R., Welling, L. L. M., \& Little, A. C. (2010). The health of a nation predicts their mate preferences: cross-cultural variation in women's preferences for masculinized male faces. Proceedings of the Royal Society of London B: Biological Sciences, 277(1692), 2405-2410. https://doi.org/10.1098/rspb.2009.2184

Dixson, B. J. W., Blake, K. R., Denson, T. F., Gooda-Vossos, A., O’Dean, S. M., Sulikowski, D., Rantala, M. J., \& Brooks, R. C. (2018). The role of mating context and fecundability in women's preferences for men's facial masculinity and beardedness.

Psychoneuroendocrinology, 93, 90-102. https://doi.org/10.1016/j.psyneuen.2018.04.007

Dixson, B. J. W., Duncan, M., \& Dixson, A. F. (2015). The Role of Breast Size and Areolar Pigmentation in Perceptions of Women's Sexual Attractiveness, Reproductive Health, Sexual Maturity, Maternal Nurturing Abilities, and Age. Archives of Sexual Behavior, 44(6), 1685-1695. https://doi.org/10.1007/s10508-015-0516-2 
Dixson, B. J. W., Grimshaw, G. M., Linklater, W. L., \& Dixson, A. F. (2011). Eye-tracking of men's preferences for waist-to-hip ratio and breast size of women. Archives of Sexual Behavior, 40(1), 43-50. https://doi.org/10.1007/s10508-009-9523-5

Dunn, M. J., \& Hill, A. (2014). Manipulated luxury-apartment ownership enhances opposite-sex attraction in females but not males. Journal of Evolutionary Psychology, 12(1), 1-17.

Dunn, M. J., \& Searle, R. (2010). Effect of manipulated prestige-car ownership on both sex attractiveness ratings. British Journal of Psychology, 101(1), 69-80.

Durante, K. M., Li, N. P., \& Haselton, M. G. (2008). Changes in women's choice of dress across the ovulatory cycle: naturalistic and laboratory task-based evidence. Personality \& Social Psychology Bulletin, 34(11), 1451-1460. https://doi.org/10.1177/0146167208323103

Edwards, E. A., \& Duntley, S. Q. (1939). The pigments and color of living human skin. American Journal of Anatomy, 65,1-33.

Eisenbruch, A. B., Simmons, Z. L., \& Roney, J. R. (2015). Lady in red: Hormonal predictors of women's clothing choices. Psychological Science, 26(8), 1332-1338. https://doi.org/10.1177/0956797615586403

Elliot, A. J., Greitemeyer, T., \& Pazda, A. D. (2013). Women's use of red clothing as a sexual signal in intersexual interaction. Journal of Experimental Social Psychology, 49(3), 599602.

Fink, B., \& Penton-Voak, I. S. (2002). Evolutionary psychology of facial attractiveness. Current Directions in Psychological Science, 11(5), 154-158. https://doi.org/https://doi.org/10.1111/1467-8721.00190

Fisher, R. (1930). The Genetical Theory of Natural Selection. The Clarendon Press.

Folstad, I., \& Karter, A. (1992). Parasites, bright males, and the immunocompetence handicap. The American Naturalist, 139(3), 603-622.

Foo, Y. Z., Nakagawa, S., Rhodes, G., \& Simmons, L. W. (2017). The effects of sex hormones on immune function: a meta-analysis. Biological Reviews, 92(1), 551-571. https://doi.org/10.1111/brv.12243

Frederick, D. A., \& Haselton, M. G. (2007). Why is muscularity sexy? Tests of the fitness indicator hypothesis. Personality and Social Psychology Bulletin, 33(8), 1167-1183. https://doi.org/10.1177/0146167207303022

Furnham, A., Dias, M., \& McClelland, A. (1998). The role of body weight, waist-to-hip ratio, and breast size in judgments of female attractiveness. Sex Roles, 39, 311-326. https://doi.org/https://doi.org/10.1023/A:1018810723493

Gangestad, S. W., Dinh, T., Grebe, N. M., Giudice, M. Del, \& Thompson, M. E. (2019). Psychological cycle shifts redux: Revisiting a preregistered study examining preferences for muscularity. Evolution and Human Behavior, 40, 501-516. https://doi.org/10.1016/j.evolhumbehav.2019.05.005

Gangestad, S. W., Thornhill, R., \& Yeo, R. A. (1994). Facial attractiveness, developmental 
stability, and fluctuating asymmetry. Science, 15(2), 73-85. https://doi.org/https://doi.org/10.1016/0162-3095(94)90018-3

Gao, Z., Gao, S., Xu, L., Zheng, X., Ma, X., Luo, L., \& Kendrick, K. M. (2017). Women prefer men who use metaphorical language when paying compliments in a romantic context. Scientific Reports, 7, 40871. https://doi.org/10.1038/srep40871

Gao, Z., Yang, Q., Ma, X., Becker, B., Li, K., Zhou, F., \& Kendrick, K. M. (2017). Men who compliment a woman's appearance using metaphorical language: Associations with creativity, masculinity, intelligence and attractiveness. Frontiers in Psychology, 8, 2185. https://doi.org/10.3389/fpsyg.2017.02185

Gaulin, S., \& Boster, J. (1985). Cross-cultural differences in sexual dimorphism. Is there any variance to be explained? Ethology and Sociobiology, 6(4), 219-225. https://doi.org/10.1016/0162-3095(85)90014-7

Gildersleeve, K., Haselton, M. G., \& Fales, M. R. (2014). Meta-analyses and p-curves support robust cycle shifts in women's mate preferences: reply to Wood and Carden (2014). Psychological Bulletin, 140(5), 1272-1280. https://doi.org/dx.doi.org/10.1037/a0037714

Goetz, C. D., Pillsworth, E. G., Buss, D. M., \& Conroy-Beam, D. (2019). Evolutionary mismatch in mating. Frontiers in Psychology, 10, 2709. https://doi.org/10.3389/fpsyg.2019.02709

Gomes, C. M., \& Boesch, C. (2009). Wild chimpanzees exchange meat for sex on a long-term basis. PLoS ONE, 4(4), e5116. https://doi.org/10.1371/journal.pone.0005116

Gouda-Vossos, A., Brooks, R. C., \& Dixson, B. J. W. (2019). The interplay between economic status and attractiveness, and the importance of attire in mate choice judgments. Frontiers in Psychology, 10, 462. https://doi.org/10.3389/fpsyg.2019.00462

Gregor, T. (1985). Anxious pleasures: The sexual lives of an Amazonian people. Chicago: University of Chicago Press.

Grillot, R. L., Simmons, Z. L., Lukaszewski, A. W., \& Roney, J. R. (2014). Hormonal and morphological predictors of women's body attractiveness. Evolution and Human Behavior, 35(3), 176-183. https://doi.org/10.1016/j.evolhumbehav.2014.01.001

Gwynne, D. T. (2008). Sexual conflict over nuptial gifts in insects. Annual Review of Entomology, 53, 83-101. https://doi.org/10.1146/annurev.ento.53.103106.093423

Han, C., Wang, H., Hahn, A. C., Fisher, C. I., Kandrik, M., Fasolt, V., Morrison, D. K., Lee, A. J., Holzleitner, I. J., DeBruine, L. M., \& Jones, B. C. (2018). Cultural differences in preferences for facial coloration. Evolution and Human Behavior, 39(2), 154-159. https://doi.org/10.1016/j.evolhumbehav.2017.11.005

Havlíček, J., \& Roberts, S. C. (2009). MHC-correlated mate choice in humans: A review. Psychoneuroendocrinology, 34(4), 497-512. https://doi.org/10.1016/j.psyneuen.2008.10.007

Havlíček, J., Třebický, V., Valentova, J. V., Kleisner, K., Akoko, R. M., Fialová, J., Jash, R., Kočnar, T., Pereira, K. J., Štěrbová, Z., Varella, M. A. C., Vokurková, J., Vunan, E., \& Roberts, S. C. (2017). Men's preferences for women's breast size and shape in four 
cultures. Evolution and Human Behavior, 38(2), 217-226.

https://doi.org/10.1016/j.evolhumbehav.2016.10.002

Havlíček, J., Winternitz, J., \& Roberts, S. C. (2020). MHC-associated odour preferences and human mate choice: near and far horizons. Philosophical Transactions of the Royal Society B: Biological Sciences, 375(1800), 20190260. https://doi.org/10.1098/rstb.2019.0260

Hendrie, C., Chapman, R., \& Gill, C. (2020). Women's strategic use of clothing and make-up. Human Ethology, 35, 16-26. https://doi.org/10.22330/he/35/016-026

Hendrie, C. A., Mannion, H. D., \& Godfrey, G. K. (2009). Evidence to suggest that nightclubs

function as human sexual display grounds. Behaviour, 146(10), 1331-1348.

Hill, E. M., Nocks, E. S., \& Gardner, L. (1987). Physical attractiveness: Manipulation by physique and status displays. Ethology and Sociobiology, 8(2), 143-154.

Holmberg, A. R. (1969). Nomads of the long Bow: The Siriono of eastern Bolivia. Garden City: Natural History Press.

Hu, S., Xiong, J., Fu, P., Qiao, L., Tan, J., Jin, L., \& Tang, K. (2017). Signatures of personality on dense 3D facial images. Scientific Reports, 7(1), 1-10. https://doi.org/10.1038/s41598$\underline{017-00071-5}$

Hughes, S. M., \& Aung, T. (2017). Modern-day female preferences for resources and provisioning by long-term mates. Evolutionary Behavioral Sciences, 11(3), 242-261.

Hughes, S. M., Aung, T., Harrison, M. A., Lafayette, J. N., \& Gallup, G. G. (2020). Experimental evidence for sex differences in sexual variety preferences: Support for the Coolidge Effect in humans. Archives of Sexual Behavior.

Janicke, T., Häderer, I. K., Lajeunesse, M. J., \& Anthes, N. (2016). Darwinian sex roles confirmed across the animal kingdom. Science Advances, 2(2), e1500983. https://doi.org/10.1126/sciadv.1500983

Jasieńska, G., Ziomkiewicz, A., Ellison, P. T., Lipson, S. F., \& Thune, I. (2004). Large breasts and narrow waists indicate high reproductive potential in women. Proceedings of the Royal Society B: Biological Sciences, 271(1545), 1213-1217. https://doi.org/10.1098/rspb.2004.2712

Javed, A., \& Lteif, A. (2013). Development of the human breast. Seminars in Plastic Surgery, 27(1), 5-12. https://doi.org/10.1055/s-0033-1343989

Jones, A. G., \& Ratterman, N. L. (2009). Mate choice and sexual selection: what have we learned since Darwin? Proceedings of the National Academy of Sciences of the United States of America, 106(Supplement 1), 10001-10008.

https://doi.org/10.1073/pnas.0901129106

Jones, A. L., Kramer, R. S. S., \& Ward, R. (2012). Signals of personality and health: The contributions of facial shape, skin texture and viewing angle. Journal of Experimental Psychology: Human Perception and Performance, 38(6), 1353-1361. https://doi.org/https://doi.org/10.1037/a0027078 
Jones, B. C., Hahn, A. C., Fisher, C. I., Wang, H., Kandrik, M., Han, C., Fasolt, V., Morrison, D., Lee, A. J., Holzleitner, I. J., O’Shea, K. J., Roberts, S. C., Little, A. C., \& DeBruine, L. M. (2018). No compelling evidence that preferences for facial masculinity track changes in women's hormonal status. Psychological Science, 29(6), 996-1005.

https://doi.org/10.1177/0956797618760197

Jünger, J., Kordsmeyer, T. L., Gerlach, T. M., \& Penke, L. (2018). Fertile women evaluate male bodies as more attractive, regardless of masculinity. Evolution and Human Behavior, 39(4), 412-423. https://doi.org/10.1016/j.evolhumbehav.2018.03.007

Jünger, J., Motta-Mena, N. V., Cardenas, R., Bailey, D., Rosenfield, K. A., Schild, C., Penke, L., $\&$ Puts, D. A. (2018). Do women's preferences for masculine voices shift across the ovulatory cycle? Hormones and Behavior, 106, 122-134.

https://doi.org/10.1016/j.yhbeh.2018.10.008

Kanazawa, S. (2000). Scientific discoveries as cultural displays: A further test of Miller's courtship model. Evolution and Human Behavior, 21(5), 317-321. https://doi.org/10.1016/S1090-5138(00)00051-9

Kaufman, S. B., Kozbelt, A., Silvia, P., Kaufman, J. C., Ramesh, S., \& Feist, G. J. (2014). Who finds Bill Gates sexy? Creative mate preferences as a function of cognitive ability, personality, and creative achievement. The Journal of Creative Behavior, 50(4), 294307.

Kordsmeyer, T. L., Hunt, J., Puts, D. A., Ostner, J., \& Penke, L. (2018). The relative importance of intra- and intersexual selection on human male sexually dimorphic traits. Evolution and Human Behavior, 39(4), 424-436. https://doi.org/10.1016/j.evolhumbehav.2018.03.008

Kościński, K., Makarewicz, R., \& Bartoszewicz, Z. (2020). Stereotypical and actual associations of breast size with mating-relevant traits. Archives of Sexual Behavior, 49(3), 821-836. https://doi.org/10.1007/s10508-019-1464-z

Kramer, R. S. S., \& Ward, R. (2010). Internal Facial Features are Signals of Personality and Health. Quarterly Journal of Experimental Psychology, 63(11), 2273-2287. https://doi.org/10.1080/17470211003770912

Krams, I., Luoto, S., Rubika, A., Krama, T., Elferts, D., Kecko, S., Skrinda, I., Moore, F., Krams, R., \& Rantala, M. J. (2019). A head start for life history development? Family income mediates associations between body height and immune response in men. American Journal of Physical Anthropology, 168(3), 421-427. https://doi.org/10.1002/ajpa.23754

Kuzawa, C. W. (2007). Developmental origins of life history: growth, productivity, and reproduction. American Journal of Human Biology, 19(5), 654-661.

Lange, B. P. (2011). Male proneness to verbal display production. Acta Linguistica, 5, 97-104.

Lange, B. P., \& Euler, H. A. (2014). Writers have groupies, too: High quality literature production and mating success. Evolutionary Behavioral Sciences, 8(1), 20-30. https://doi.org/10.1037/h0097246

Lassek, W. D., \& Gaulin, S. J. C. (2008). Waist-hip ratio and cognitive ability: is gluteofemoral 
fat a privileged store of neurodevelopmental resources? Evolution and Human Behavior, 29(1), 26-34. https://doi.org/10.1016/j.evolhumbehav.2007.07.005

Lassek, W. D., \& Gaulin, S. J. C. (2009). Costs and benefits of fat-free muscle mass in men: relationship to mating success, dietary requirements, and native immunity. Evolution and Human Behavior, 30(5), 322-328. https://doi.org/10.1016/j.evolhumbehav.2009.04.002

Lassek, W. D., \& Gaulin, S. J. (2019). Evidence supporting nubility and reproductive value as the key to human female physical attractiveness. Evolution and Human Behavior, 40(5), 408-419.

Law Smith, M. J., Perrett, D. I., Jones, B. C., Cornwell, R. E., Moore, F. R., Feinberg, D. R., Boothroyd, L. G., Durrani, S. J., Stirrat, M. R., Whiten, S., Pitman, R. M., \& Hillier, S. G. (2006). Facial appearance is a cue to oestrogen levels in women. Proceedings. Biological Sciences / The Royal Society, 273(1583), 135-140. https://doi.org/10.1098/rspb.2005.3296

Lee, A. J., Wright, M. J., Martin, N. G., Keller, M. C., \& Zietsch, B. P. (2017). Facial trustworthiness is associated with heritable aspects of face shape. Adaptive Human Behavior and Physiology, 3(4), 351-364. https://doi.org/10.1007/s40750-017-0073-0

Lee, L., Loewenstein, G., Ariely, D., Hong, J., \& Young, J. (2008). If I'm not hot, are you hot or not? Psychological Science, 19(7), 669. https://doi.org/10.1111/j.1467-9280.2008.02141.x

Lennon, S. J., Adomaitis, A. D., Koo, J., \& Johnson, K. K. (2017). Dress and sex: A review of empirical research involving human participants and published in refereed journals. Fashion and Textiles, 4(1), 14.

Lewis, D. M. G., Russell, E. M., Al-Shawaf, L., Ta, V., Senveli, Z., Ickes, W., ... Mogilski, J. K. (2017). Why women wear high heels: Evolution, lumbar curvature, and attractiveness. Frontiers in Psychology, 8, 1875. https://doi.org/10.3389/fpsyg.2017.01875

Lewis, S., \& South, A. (2012). The evolution of animal nuptial gifts. Advances in the Study of Behavior, 44, 53-97. https://doi.org/10.1016/B978-0-12-394288-3.00002-2

Li, N. P., Bailey, J. M., Kenrick, D. T., \& Linsenmeier, J. A. W. (2002). The necessities and luxuries of mate preferences: Testing the tradeoffs. Journal of Personality and Social Psychology, 82(6), 947-955.

Li, N. P., van Vugt, M., \& Colarelli, S. M. (2018). The evolutionary mismatch hypothesis: Implications for psychological science. Current Directions in Psychological Science, 27(1), 38-44.

Lie, H. C., Rhodes, G., \& Simmons, L. W. (2008). Genetic diversity revealed in human faces. Evolution; International Journal of Organic Evolution, 62(10), 2473-2486. https://doi.org/10.1111/j.1558-5646.2008.00478.x

Lie, H. C., Simmons, L. W., \& Rhodes, G. (2009). Does genetic diversity predict health in humans? PloS One, 4(7), e6391. https://doi.org/10.1371/journal.pone.0006391

Lipson, S. F., \& Ellison, P. T. (1996). Comparison of salivary steroid profiles in naturally occurring conception and non-conception cycles. Human Reproduction, 11(10), 2090-2096. https://doi.org/10.1093/oxfordjournals.humrep.a019055. 
Little, A. C., Apicella, C. L., \& Marlowe, F. W. (2007). Preferences for symmetry in human faces in two cultures: data from the UK and the Hadza, an isolated group of huntergatherers. Proceedings. Biological Sciences / The Royal Society, 274(1629), 3113-3117. https://doi.org/10.1098/rspb.2007.0895

Little, A. C., Burt, D. M., \& Perrett, D. I. (2006). Assortative mating for perceived facial personality traits. Personality and Individual Differences, 40(5), 973-984. https://doi.org/10.1016/j.paid.2005.09.016

Luoto, S. (2019a). An updated theoretical framework for human sexual selection: from ecology, genetics, and life history to extended phenotypes. Adaptive Human Behavior and Physiology, 5(1), 48-102. https://doi.org/10.1007/s40750-018-0103-6

Luoto, S. (2019b). Response to Commentaries: Life history genetics, fluid intelligence, and extended phenotypes. Adaptive Human Behavior and Physiology, 5(1), 112-115. https://doi.org/10.1007/s40750-019-0109-8

Luoto, S., Krama, T., Rubika, A., Borráz-León, J. I., Trakimas, G., Elferts, D., Skrinda, I., Krams, R., Rantala, M. J., \& Krams, I. (forthcoming). Socioeconomic position, immune function, and its physiological markers.

Luoto, S., Krams, I., \& Rantala, M. J. (2019). A life history approach to the female sexual orientation spectrum: Evolution, development, causal mechanisms, and health. Archives of Sexual Behavior, 48(5), 1273-1308. https://doi.org/10.1007/s10508-018-1261-0

Madison, G., Holmquist, J., \& Vestin, M. (2018). Musical improvisation skill in a prospective partner is associated with mate value and preferences, consistent with sexual selection and parental investment theory: Implications for the origin of music. Evolution and Human Behavior, 39(1), 120-129. https://doi.org/10.1016/j.evolhumbehav.2017.10.005

Mallucci, P., \& Branford, O. A. (2012). Concepts in aesthetic breast dimensions: Analysis of the ideal breast. Journal of Plastic, Reconstructive and Aesthetic Surgery, 65(1), 8-16. https://doi.org/10.1016/j.bjps.2011.08.006

Mallucci, P., \& Branford, O. A. (2014). Population analysis of the perfect breast: A morphometric analysis. Plastic and Reconstructive Surgery, 134(3), 436-447. https://doi.org/10.1097/PRS.0000000000000485

Marcinkowska, U. M., Kozlov, M. V., Cai, H., Contreras-Garduño, J., Dixson, B. J., Oana, G. A., ... \& Prasai, K. (2014). Cross-cultural variation in men's preference for sexual dimorphism in women's faces. Biology Letters, 10(4), 20130850.

Marcinkowska, U. M., Rantala, M. J., Lee, A. J., Kozlov, M. V., Aavik, T., Cai, H., ... \& Onyishi, I. E. (2019). Women's preferences for men's facial masculinity are strongest under favorable ecological conditions. Scientific Reports, 9(1), 1-10.

Marioni, R. E., Batty, G. D., Hayward, C., Kerr, S. M., Campbell, A., Hocking, L. J., ... \& Deary, I. J. (2014). Common genetic variants explain the majority of the correlation between height and intelligence: the generation Scotland study. Behavior Genetics, 44(2), 91-96.

Mazur, A., \& Booth, A. (1998). Testosterone and dominance in men. The Behavioral and Brain Sciences, 21(3), 353-397. http://www.ncbi.nlm.nih.gov/pubmed/10097017 
McEvoy, B. P., \& Visscher, P. M. (2009). Genetics of human height. Economics and Human Biology, 7, 294-306.

Miller, G. F. (1999). Sexual selection for cultural displays. In R. Dunbar, C. Knight, \& C. Power (Eds.), The Evolution of Culture (pp. 71-91). New Brunswick, NJ: Rutgers University Press.

Miller, G. F. (2001). Aesthetic fitness: How sexual selection shaped artistic virtuosity as a fitness indicator and aesthetic preferences as mate choice criteria. Bulletin of Psychology and the Arts, 2(1), 20-25.

Miller, G. F., \& Todd, P. M. (1998). Mate choice turns cognitive. Trends in Cognitive Sciences, 2(5), 190-198.

Mogilski, J. K., \& Welling, L. L. (2017). The relative importance of sexual dimorphism, fluctuating asymmetry, and color cues to health during evaluation of potential partners' facial photographs. Human Nature, 28, 53-75.

Møller, A. P., Soler, M., \& Thornhill, R. (1995). Breast asymmetry, sexual selection, and human reproductive success. Ethology and Sociobiology, 16, 207-219.

Møller, A. P., \& Thornhill, R. (1998). Bilateral symmetry and sexual selection: a meta-analysis. The American Naturalist, 151(2), 174-192. https://doi.org/10.1086/286110

Moore, F. R., Coetzee, V., Contreras-Garduno, J., Debruine, L. M., Kleisner, K., Krams, I., Marcinkowska, U., Nord, A., Perrett, D. I., Rantala, M. J., Schaum, N., \& Suzuki, T. N. (2013). Cross-cultural variation in women's preferences for cues to sex- and stresshormones in the male face. Biology Letters, 9(3), 20130050. https://doi.org/10.1098/rsbl.2013.0050

Morris, P. H., White, J., Morrison, E. R., \& Fisher, K. (2013). High heels as supernormal stimuli: How wearing high heels affects judgements of female attractiveness. Evolution and Human Behavior. https://doi.org/10.1016/j.evolhumbehav.2012.11.006

Murasko, J. E. (2020). Height, Marriage, and Partner Characteristics for Women in Low-and Middle-Income Countries. Economics \& Human Biology, 100876.

Panza, J., Quyyumi, A., Brush, J., \& Epstein, S. (1990). Abnormal endothelium-dependent vascular relaxation in patients with essential hypertension. New England Journal of Medicine, 323(1), 22-27. https://doi.org/10.1056/NEJM199007053230105

Paunonen, S. V., Ewan, K., Earthy, J., Lefave, S., \& Goldberg, H. (1999). Facial features as personality cues. Journal of Personality, 67(3), 555-583. https://doi.org/10.1111/14676494.00065

Pazhoohi, F., Garza, R., \& Kingstone, A. (2020). Effects of breast size, intermammary cleft distance (cleavage) and ptosis on perceived attractiveness, health, fertility and age: Do life history, self-perceived mate value and sexism attitude play a role? Adaptive Human Behavior and Physiology, 6, 75-92. https://doi.org/10.1007/s40750-020-00129-1 
Pawłowski, B., Borkowska, B., Nowak, J., Augustyniak, D., Drulis-Kawa, Z. 2018. Human body symmetry and immune efficacy in healthy adults. American Journal of Physical Anthropology 167, 207-216.

Pazhoohi, F., \& Kingstone, A. (2020). Sex difference on the importance of veiling: A crosscultural investigation. Cross-Cultural Research, 1069397120931031.

Penton-Voak, I. S., \& Chen, J. Y. (2004). High salivary testosterone is linked to masculine male facial appearance in humans. Evolution and Human Behavior, 25(4), 229-241. https://doi.org/10.1016/j.evolhumbehav.2004.04.003

Penton-Voak, I. S., Jones, B. C., Little, A. C., Baker, S., Tiddeman, B., Burt, D. M., \& Perrett, D. I. (2001). Symmetry, sexual dimorphism in facial proportions and male facial attractiveness. Proceedings of the Royal Society of London B: Biological Sciences, 268(1476), 1617-1623. https://doi.org/10.1098/rspb.2001.1703

Penton-Voak, I. S., Perrett, D. I., Castles, D. L., Kobayashi, T., Burt, D. M., Murray, L. K., \& Minamisawa, R. (1999). Menstrual cycle alters face preference. Nature, 399(6738), 741742. https://doi.org/10.1038/21557

Penton-Voak, I. S., Pound, N., Little, A. C., \& Perrett, D. I. (2006). Personality judgments from natural and composite facial images: More evidence for a "kernel of truth" in social perception. Social Cognition, 24(5), 607-640. https://doi.org/10.1521/soco.2006.24.5.607

Perrett, D. I., Burt, D. M., Penton-Voak, I. S., Lee, K. J., Rowland, D. A., \& Edwards, R. (1999). Symmetry and human facial attractiveness. Perception, 307, 295-307.

Perrett, D. I., Lee, K. J., Penton-Voak, I. S., Rowland, D., Yoshikawa, S., \& Burt, D. M. (1998). Effects of sexual dimorphism on facialattractiveness. Nature, 394(August), 884-887.

Pezdirc, K., Rollo, M. E., Whitehead, R., Hutchesson, M. J., Ozakinci, G., Perrett, D. I., \& Collins, C. E. (2017). Perceptions of carotenoid and melanin colouration in faces among young Australian adults. Australian Journal of Psychology, 1-6. https://doi.org/10.1111/ajpy.12163

Phalane, K. G., Tribe, C., Steel, H. C., Cholo, M. C., \& Coetzee, V. (2017). Facial appearance reveals immunity in African men. Scientific Reports, 7(1), 7443.

Pollock, D. (2002). Partible paternity and multiple maternity among the Kulina. In S. Beckerman \& P. Valentine (Eds.), Cultures of multiple fathers: The theory of practice of partible paternity in lowland South America (pp. 42-61). Gainesville: University Press of Florida.

Pound, N., Lawson, D. W., Toma, A. M., Richmond, S., Zhurov, A. I., \& Penton-voak, I. S. (2014). Facial fluctuating asymmetry is not associated with childhood ill-health in a large British cohort study. Proceedings of the Royal Society of London B, 281, 20141639. https://doi.org/http://dx.doi.org/10.1098/rspb.2014.1639

Prokop, P., \& Švancárová, J. (2020). Wearing high heels as female mating strategy. Personality and Individual Differences, 152, 109558. https://doi.org/10.1016/j.paid.2019.109558

Puts, D. A. (2010). Beauty and the beast: Mechanisms of sexual selection in humans. Evolution and Human Behavior, 31(3), 157-175. https://doi.org/10.1016/j.evolhumbehav.2010.02.005 
Rantala, M. J., Coetzee, V., Moore, F. R., Skrinda, I., Kecko, S., Krama, T., ... \& Krams, I. (2013a). Adiposity, compared with masculinity, serves as a more valid cue to immunocompetence in human mate choice. Proceedings of the Royal Society B: Biological Sciences, 280(1751), 20122495.

Rantala, M. J., Coetzee, V., Moore, F. R., Skrinda, I., Kecko, S., Krama, T., ... \& Krams, I. (2013b). Facial attractiveness is related to women's cortisol and body fat, but not with immune responsiveness. Biology Letters, 9(4), 20130255.

Rantala, M. J., Luoto, S., Krama, T., \& Krams, I. (2019). Eating disorders: An evolutionary psychoneuroimmunological approach. Frontiers in Psychology, 10. https://doi.org/10.3389/fpsyg.2019.02200

Rantala, M. J., Luoto, S., Krams, I., \& Karlsson, H. (2018). Depression subtyping based on evolutionary psychiatry: Proximate mechanisms and ultimate functions. Brain, Behavior, and Immunity, 69, 603-617. https://doi.org/10.1016/j.bbi.2017.10.012

Re, D. E., Whitehead, R. D., Xiao, D., \& Perrett, D. I. (2011). Oxygenated-blood colour change thresholds for perceived facial redness, health, and attractiveness. PloS One, 6(3), e17859. https://doi.org/10.1371/journal.pone.0017859

Rhodes, G., Zebrowitz, L. A., Clark, A., Kalick, S. M., Hightower, A., \& McKay, R. (2001). Do facial averageness and symmetry signal health? Evolution and Human Behavior, 22(1), 3146. https://doi.org/https://doi.org/10.1016/S1090-5138(00)00060-X

Roberts, S. C., Little, A. C., Gosling, L. M., Perrett, D. I., Carter, V., Jones, B. C., Penton-Voak, I. S., \& Petrie, M. (2005). MHC-heterozygosity and human facial attractiveness. Evolution and Human Behavior, 26(3), 213-226. https://doi.org/10.1016/j.evolhumbehav.2004.09.002

Rotwein, P. (2020). Revisiting the Population Genetics of Human Height. Journal of the Endocrine Society, 4(4), bvaa025.

Rubika, A., Luoto, S., Krama, T., Trakimas, G., Rantala, M. J., Moore, F., Skrinda, I., Elferts, D., Krams, R., Contreras-Garduño, J., \& Krams, I. (2020). Women's socioeconomic position in ontogeny is associated with improved immune function and lower stress, but not with height. Scientific Reports, 10, 11517. https://doi.org/10.1038/s41598-020-68217$\underline{6}$

Scelza, B. A., \& Prall, S. P. (2018). Partner preferences in the context of concurrency: What Himba want in formal and informal partners. Evolution and Human Behavior, 39(2), 212-219. https://doi.org/10.1016/j.evolhumbehav.2017.12.005

Schaedelin, F. C., \& Taborsky, M. (2009). Extended phenotypes as signals. Biological Reviews, 84(2), 293-313. https://doi.org/10.1111/j.1469-185X.2008.00075.X

Schwarz, S., \& Hassebrauck, M. (2012). Sex and age differences in mate-selection preferences. Human Nature, 23(4), 447-466.

Scott, I. M. L., Pound, N., Stephen, I. D., Clark, A. P., Penton-Voak, I. S. (2010) Does masculinity matter? The contribution of masculine face shape to male attractiveness in humans. PLoS ONE 5(10): e13585. doi:10.1371/journal.pone.0013585 
Scutt, D., Manning, J. T., Whitehouse, G. H., Leinster, S. J., \& Massey, C. P. (1997). The relationship between breast asymmetry, breast size and the occurrence of breast cancer. The British Journal of Radiology, 70(838), 1017-1021. http://www.ncbi.nlm.nih.gov/pubmed/9404205

Sell, A., Cosmides, L., Tooby, J., Sznycer, D., Rueden, C. Von, Sell, A., Cosmides, L., Tooby, J., Sznycer, D., Rueden, C. Von, \& Gurven, M. (2009). Human adaptations for the visual assessment of strength and fighting ability from the body and face. Proceedings of the Royal Society B: Biological Sciences, 276, 575-584. https://doi.org/10.1098/rspb.2008.1177

Sell, A., Lukazsweski, A. W., \& Townsley, M. (2017). Cues of upper body strength account for most of the variance in men's bodily attractiveness. Proceedings of the Royal Society B: Biological Sciences, 284(1869), 20171819. https://doi.org/10.1098/rspb.2017.1819

Shuler, G. A., \& McCord, D. M. (2010). Determinants of male attractiveness: "Hotness" ratings as a function of perceived resources. American Journal of Psychological Research, 6(1), $10-23$.

Silventoinen, K., Sammalisto, S., Perola, M., Boomsma, D. I., Cornes, B. K., Davis, C., ... Kaprio, J. (2003). Heritability of adult body height: A comparative study of twin cohorts in eight countries. Twin Research, 6, 399-408.

Singh, D. (1993a). Body shape and women's attractiveness - The critical role of waist-to-hip ratio. Human Nature, 4(3), 297-321. https://doi.org/10.1007/BF02692203

Singh, D. (1993b). Adaptive significance of female physical attractiveness: role of waist-to-hip ratio. Journal of Personality and Social Psychology, 65(2), 293-307. http://www.ncbi.nlm.nih.gov/pubmed/8366421

Singh, D. (1995). Female health, attractiveness, and desirability for relationships: Role of breast asymmetry and waist-to-hip ratio. Ethology and Sociobiology, 16(6), 465-481. https://doi.org/10.1016/0162-3095(95)00073-9

Singh, D., \& Young, R. K. (1995). Body weight, waist-to-hip ratio, breasts, and hips: Role in judgments of female attractiveness and desirability for relationships. Ethology and Sociobiology, 16(6), 483-507. https://doi.org/10.1016/0162-3095(95)00074-7

Sorokowska, A., Pietrowski, D., Schäfer, L., Kromer, J., Schmidt, A. H., Sauter, J., Hummel, T., \& Croy, I. (2018). Human Leukocyte Antigen similarity decreases partners' and strangers' body odor attractiveness for women not using hormonal contraception. Hormones and Behavior, 106, 144-149. https://doi.org/10.1016/j.yhbeh.2018.10.007

Stahl, W., Heinrich, U., Jungmann, H., Laar, J. Von, Schietzel, M., Sies, H., Tronnier, H., von Laar, J., Schietzel, M., Sies, H., \& Tronnier, H. (1998). Increased dermal carotenoid levels assessed by noninvasive reflection spectrophotometry correlate with serum levels in women ingesting Betatene. The Journal of Nutrition, 128(January), 903-907. https://doi.org/https://doi.org/10.1093/jn/128.5.903

Stephen, I. D., Coetzee, V., Law Smith, M., \& Perrett, D. I. (2009). Skin blood perfusion and oxygenation colour affect perceived human health. PLOS ONE, 4(4), e5083.

https://doi.org/10.1371/journal.pone.0005083 
Stephen, I. D., Coetzee, V., \& Perrett, D. I. (2011). Carotenoid and melanin pigment coloration affect perceived human health. Evolution and Human Behavior, 32(3), 216-227. https://doi.org/10.1016/j.evolhumbehav.2010.09.003

Stephen, I. D., Hiew, V., Coetzee, V., Tiddeman, B. P., \& Perrett, D. I. (2017). Facial shape analysis identifies valid cues to aspects of physiological health in Caucasian, Asian, and African populations. Frontiers in Psychology, 8(OCT). https://doi.org/10.3389/fpsyg.2017.01883

Stephen, I. D., Law Smith, M. J., Stirrat, M. R., \& Perrett, D. I. (2009). Facial skin coloration affects perceived health of human faces. International Journal of Primatology, 30(6), 845857. https://doi.org/10.1007/s10764-009-9380-z

Stephen, I. D., Scott, I. M. L. I. M. L., Coetzee, V., Pound, N., Perrett, D. I., \& Penton-Voak, I. S. (2012). Cross-cultural effects of color, but not morphological masculinity, on perceived attractiveness of men's faces. Evolution and Human Behavior, 33(4), 260-267. https://doi.org/10.1016/j.evolhumbehav.2011.10.003

Stephen, I. D., Wei, T. K., \& Tan, K. W. (2015). Healthy body, healthy face ? Evolutionary approaches to attractiveness perception. In Culture and Cognition: A Collection of Critical Essays. Peter Lang International Publishers. https://doi.org/10.3726/978-3-0351-0826-2

Stephen, I. D., Salter, D. L. H., Tan, K. W., Tan, C. B. Y., \& Stevenson, R. J. (2018): Sexual dimorphism and attractiveness in Asian and White faces, Visual Cognition, DOI: $10.1080 / 13506285.2018 .1475437$

Stulp, G., \& Barrett, L. (2016). Evolutionary perspectives on human height variation. Biological Reviews, 91(1), 206-234.

Stulp, G., Buunk, A. P., Kurzban, R., \& Verhulst, S. (2013). The height of choosiness: mutual mate choice for stature results in suboptimal pair formation for both sexes. Animal Behaviour, 86(1), 37-46.

Stulp, G., Buunk, A. P., Verhulst, S., \& Pollet, T. V. (2015). Human height is positively related to interpersonal dominance in dyadic interactions. PloS One, 10(2), e0117860.

Stulp, G., Simons, M. J., Grasman, S., \& Pollet, T. V. (2017). Assortative mating for human height: A meta-analysis. American Journal of Human Biology, 29(1), e22917.

Sugiyama, L. S. (2015). Physical attractiveness: An adaptationist perspective. In D. M. Buss (Ed.), The handbook of evolutionary psychology (2nd ed., pp. 317-384). Wiley Online Library. https://doi.org/10.1002/9781119125563.evpsych112.

Sundet, J. M., Tambs, K., Harris, J. R., Magnus, P., \& Torjussen, T. M. (2005). Resolving the genetic and environmental sources of the correlation between height and intelligence: A study of nearly 2600 Norwegian male twin pairs. Twin Research and Human Genetics, $8(4), 307-311$.

Sundie, J. M., Kenrick, D. T., Griskevicius, V., Tybur, J. M., Vohs, K. D., \& Beal, D. J. (2011). Peacocks, Porsches, and Thorstein Veblen: Conspicuous consumption as a sexual signaling system. Journal of Personality and Social Psychology, 100(4), 664-680. 
Swaddle, J. P., \& Reierson, G. W. (2002). Testosterone increases perceived dominance but not attractiveness in human males. Proceedings of the Royal Society B: Biological Sciences, 269(1507), 2285-2289. https://doi.org/10.1098/rspb.2002.2165

Swami, V., Jones, J., Einon, D., \& Furnham, A. (2009). Men's preferences for women's profile waist-to-hip ratio, breast size, and ethnic group in Britain and South Africa. British Journal of Psychology, 100(Pt 2), 313-325. https://doi.org/10.1348/000712608X329525

Swami, V., \& Tovée, M. J. (2013). Resource security impacts men's female breast size preferences. PLoS ONE, 8(3), e57623. https://doi.org/10.1371/journal.pone.0057623

Swift-Gallant, A., Johnson, B. A., Di Rita, V., \& Breedlove, S. M. (2020). Through a glass, darkly: Human digit ratios reflect prenatal androgens, imperfectly. Hormones and Behavior, 120, 104686.

Tan, K. W., Graf, B. A., Mitra, S. R., Stephen, I. D., Wei, K., Graf, B. A., Roy, S., \& Stephen, I. D. (2017). Impact of fresh fruit smoothie consumption on apparent health of Asian faces. Evolution and Human Behavior, 38(4), 522-529. https://doi.org/10.1016/j.evolhumbehav.2017.02.004

Tan, K. W., \& Stephen, I. D. (2013). Colour detection thresholds in faces and colour patches. Perception, 42(7), 733-741. https://doi.org/10.1068/p7499

Tan, K. W., \& Stephen, I. D. (2019). Skin color preferences in a Malaysian Chinese population. Frontiers in Psychology, 10(JUN). https://doi.org/10.3389/fpsyg.2019.01352

Tan, K. W., Tiddeman, B., Stephen, I. D., Tan, K. W., Tiddeman, B., \& Stephen, I. D. (2018). Skin texture and colour predict perceived health in Asian faces. Evolution and Human Behavior, 39(3), 320-335. https://doi.org/10.1016/j.evolhumbehav.2018.02.003

Thornhill, R., \& Gangestad, S. W. (1999). Facial attractiveness. Trends in Cognitive Sciences, 3(12), 452-460. http://www.ncbi.nlm.nih.gov/pubmed/10562724

Thornhill, R., Gangestad, S. W., Miller, R., Scheyd, G., McCollough, J. K., \& Franklin, M. (2003). Major histocompatibility complex genes, symmetry, and body scent attractiveness in men and women. Behavioral Ecology, 14(5), 668-678. https://doi.org/10.1093/beheco/arg043

Tovée, M. J., \& Cornelissen, P. L. (2001). Female and male perceptions of female physical attractiveness in front-view and profile. British Journal of Psychology, 92 Part 2(Pt 2), 391-402. https://doi.org/10.1348/000712601162257

Trivers, R. (1972). Parental investment and sexual selection. In B Campbell (Ed.), Sexual Selection and the Descent of Man: 1871-1971 (pp. 136-179). Aldine.

Valentova, J. V., Bártová, K., Štěrbová, Z., \& Corrêa Varella, M. A. (2017). Influence of sexual orientation, population, homogamy, and imprinting-like effect on preferences and choices for female buttock size, breast size and shape, and WHR. Personality and Individual Differences, 104, 313-319. https://doi.org/10.1016/j.paid.2016.08.005

Van Valen, L. (1973). A new evolutionary law. Evolutionary Theory, 1, 1-30. 
Varella, M. A. C., Valentova, J. V., \& Fernández, A. M. (2017). Evolution of artistic and aesthetic propensities through female competitive ornamentation. In M. L. Fisher (Ed.), The Oxford Handbook of Women and Competition (pp. 757-783). Oxford University Press. https://doi.org/10.1093/oxfordhb/9780199376377.013.46

Vizental, A. (2010). Meaning, image and attitude (I). Journal of Humanistic and Social Studies, 1(2), 77-88.

Waitt, C., \& Little, A. C. (2006). Preferences for symmetry in conspecific facial shape among Macaca mulatta. International Journal of Primatology, 27(1), 133-145. https://doi.org/10.1007/s10764-005-9015-y

Watkins, C., \& Leitch, A. (2020). Using sexual selection theories to examine contextual variation in heterosexual women's orientation toward high heels. Archives of Sexual Behavior, 49, 849-860. https://doi.org/10.1007/s10508-019-01539-3

Wedekind, C., Seebeck, T., Bettens, F., \& Paepke, A. J. (2006). The intensity of human body odors and the MHC: Should we expect a link? Evolutionary Psychology, 4(1), 147470490600400. https://doi.org/10.1177/147470490600400106

Whitehead, R. D., Coetzee, V., Ozakinci, G., \& Perrett, D. I. (2012). Cross-cultural effects of fruit and vegetable consumption on skin color. American Journal of Public Health, 102(2), 212-213. https://doi.org/10.2105/AJPH.2011.300495

Winegard, B., Winegard, B., \& Geary, D. C. (2018). The status competition model of cultural production. Evolutionary Psychological Science, 4(4), 351-371.

Winternitz, J., Abbate, J. L., Huchard, E., Havlíček, J., \& Garamszegi, L. Z. (2017). Patterns of MHC-dependent mate selection in humans and nonhuman primates: a meta-analysis. Molecular Ecology, 26(2), 668-688. https://doi.org/10.1111/mec.13920

Wolf, N. (1990). The Beauty Myth: How Images of Beauty Are Used Against Women. Chato \& Windus.

Wolffhechel, K., Hahn, A. C., Jarmer, H., Fisher, C. I., Jones, B. C., \& DeBruine, L. M. (2015). Testing the utility of a data-driven approach for assessing BMI from face images. Plos One, 10(10), e0140347. https://doi.org/10.1371/journal.pone.0140347

Wollstonecraft, M. (1992/1792). A Vindication of the Rights of Woman. Boston: Peter Edes. Available at: https://www.bartleby.com/144/3.html. Retrieved on September 4, 2020.

Wood, W., Kressel, L., Joshi, P. D., \& Louie, B. (2014). Meta-analysis of menstrual cycle effects on women's mate preferences. Emotion Review, O(0), 1-21. https://doi.org/10.1177/1754073914523073

Zaadstra, B. M., Seidell, J. C., Van Noord, P. A. H., Te Velde, E. R., Habbema, J. D. F., Vrieswijk, B., \& Karbaat, J. (1993). Fat and female fecundity: Prospective study of effect of body fat distribution on conception rates. Obstetrical and Gynecological Survey, 48(7), 484-486. https://doi.org/10.1097/00006254-199307000-00022

Zaidi, A. A., White, J. D., Mattern, B. C., Liebowitz, C. R., Puts, D. A., Claes, P., \& Shriver, M. D. (2019). Facial masculinity does not appear to be a condition-dependent male ornament 
and does not reflect MHC heterozygosity in humans. Proceedings of the National Academy of Sciences, 116(5), 1633-1638.

Zebrowitz, L. A., Hall, J. a., Murphy, N. a., \& Rhodes, G. (2002). Looking smart and looking good: Facial cues to intelligence and their origins. Personality and Social Psychology Bulletin, 28(2), 238-249. https://doi.org/10.1177/0146167202282009

Żelaźniewicz, A., Nowak, J., Łącka, P., \& Pawłowski, B. (2020). Facial appearance and metabolic health biomarkers in women. Scientific Reports, 10(1), 1-8.

Zietsch, B. P., Verweij, K. J. H., \& Burri, A. V. (2012). Heritability of preferences for multiple cues of mate quality in humans. Evolution, 66(6), 1762-1772. 